\title{
Kinetic and mechanistic studies of the reactions of nitrogen monoxide and nitrite with ferryl myoglobin
}

\section{Journal Article}

Author(s):

Herold, Susanna; Rehmann, Franz-Josef K.

Publication date:

2001

Permanent link:

https://doi.org/10.3929/ethz-b-000422766

Rights / license:

In Copyright - Non-Commercial Use Permitted

Originally published in:

JBIC Journal of Biological Inorganic Chemistry 6(5-6), https://doi.org/10.1007/s007750100231 


\section{Susanna Herold • Franz-Josef K. Rehmann \\ Kinetic and mechanistic studies of the reactions of nitrogen monoxide and nitrite with ferryl myoglobin}

Received: 13 December 2000 / Accepted: 29 January 2001 / Published online: 12 April 2001

(C) SBIC 2001

\begin{abstract}
Nitrogen monoxide (nitric oxide) generated endogenously has a variety of different properties. Among others it regulates blood pressure and transmission of nerve impulses, and has been shown to exert specific toxic effects, but also, paradoxically, to protect against various toxic substances. Recent studies suggest that $\mathrm{NO}$ can serve as an antioxidant of the highly oxidizing ferryl myoglobin $\left(\mathrm{MbFe}^{\mathrm{IV}}=\mathrm{O}\right)$, which has been proposed to be at least in part responsible for the oxidative damage caused by the reperfusion of ischemic tissues. In the present work we have determined the rate constant for the reaction between $\mathrm{MbFe}^{\mathrm{IV}}=\mathrm{O}$ and $\mathrm{NO}^{\cdot}\left[(17.9 \pm 0.5) \times 10^{6} \mathrm{M}^{-1} \mathrm{~s}^{-1}\right.$ at $\mathrm{pH} 7.5$ and $20^{\circ} \mathrm{C}$ ] and we have shown that this reaction proceeds via the intermediate nitrito-metmyoglobin complex $\mathrm{MbFe}^{\mathrm{III}} \mathrm{ONO}$. Our results imply that this reaction is very likely to take place in vivo and might indeed represent a detoxifying pathway for both $\mathrm{MbFe}^{\mathrm{IV}}=\mathrm{O}$ as well as NO. Moreover, we have found that the rate of reaction of $\mathrm{MbFe}^{\mathrm{IV}}=\mathrm{O}$ with nitrite is significantly lower $\left(16 \pm 1 \mathrm{M}^{-1} \mathrm{~s}^{-1}\right.$ at $\mathrm{pH} 7.5$ and $\left.20^{\circ} \mathrm{C}\right)$. Thus, this reaction probably plays a role only when $\mathrm{NO}^{\circ}$ has been consumed completely and large concentrations of nitrite are still present. In contrast to the protecting role of $\mathrm{NO}$, the reaction with nitrite generates nitrogen dioxide which can contribute to tyrosine nitration. Indeed, we have demonstrated that nitrite can nitrate added tyrosine in the presence of iron(III) myoglobin and hydrogen peroxide.
\end{abstract}

Keywords Nitrogen monoxide $\cdot$ Nitrite $\cdot$ Ferryl myoglobin $\cdot$ Nitrotyrosine $\cdot$ Kinetics

S. Herold $(\bowtie) \cdot$ F.-J.K. Rehmann

Laboratory of Inorganic Chemistry, ETH Zürich,

Universitätsstrasse 6, 8092 Zürich, Switzerland

E-mail: herold@inorg.chem.ethz.ch

Phone: +41-1-6322858

Fax: +41-1-6321090
Abbreviations Compound I: (porphyrin'+) oxoiron(IV) · Compound II: (porphyrin)oxoiron(IV) $\mathrm{Hb}$ : hemoglobin $\cdot \mathrm{HbFeO}_{2}$ : oxyhemoglobin $\cdot \operatorname{met} \mathrm{Hb}$ : iron(III) hemoglobin - His: histidine $\cdot H R P$ :

horseradish peroxidase $\cdot L P O$ : lactoperoxidase $\cdot M b$ : myoglobin $\cdot \mathrm{MbFe}^{I I}$ : deoxymyoglobin $\cdot \mathrm{MbFeO}_{2}$ : oxymyoglobin $\cdot$ met $M b$ : iron(III) myoglobin . $M b F e^{I V}=O$ : ferryl [oxoiron(IV)] myoglobin . $\cdot M b F e^{I V}=O$ : ferryl myoglobin with a transient protein radical $\cdot M P O$ : myeloperoxidase $\cdot \mathrm{NO}_{2}$-Tyr: 3-nitrotyrosine $\cdot$ Tyr: tyrosine $\cdot$ Tyr: tyrosyl radical

\section{Introduction}

The mechanism of tissue damage caused by reperfusion of an ischemic tissue is not well understood yet. It has been proposed to be triggered by the formation of reactive oxygen and nitrogen species such as superoxide, hydrogen peroxide, hydroxyl radical, and peroxynitrite $[1,2,3,4]$. The reaction between hydrogen peroxide (present in concentrations as high as $10 \mu \mathrm{M}$ in ischemic heart muscle [5]) and myoglobin has been suggested to be a key determinant of oxidative damage in the ischemic and then reoxygenated heart [6]. Hydrogen peroxide reacts with deoxymyoglobin, $\mathrm{MbFe}^{\mathrm{II}}$ (also present in elevated concentration in ischemic oxygen-poor tissues), to generate the highly oxidizing species ferryl myoglobin, $\mathrm{MbFe}^{\mathrm{IV}}=\mathrm{O}$. In addition, the reaction of metmyoglobin with hydrogen peroxide generates the one-electron oxidized form of $\mathrm{MbFe}^{\mathrm{IV}}=\mathrm{O}$, which has an additional transient radical on the globin, ${ }^{\mathrm{MbFe}}{ }^{\mathrm{IV}}=\mathrm{O}$ [7]. The radical species generated from this reaction can damage the cell membrane, induce the release of myoglobin from ruptured myocytes, and thus lead to destabilization and subsequent liberation of free iron, providing the potential for hydroxyl radical formation [2,8]. There is direct evidence that the high oxidation state of myoglobin 
$\left(\mathrm{Fe}^{\mathrm{IV}}=\mathrm{O}\right)$ is formed in vivo. Indeed, it has been identified, through derivatization with $\mathrm{Na}_{2} \mathrm{~S}$ to form sulfomyoglobin, [9] in isolated ischemic rat hearts [10].

$\mathrm{MbFe}^{\mathrm{IV}}=\mathrm{O}$ is a strong oxidant that can promote oxidation, peroxidation $[8,11,12]$, and epoxidation of various biomolecules in vitro [7]. The reaction of several antioxidant species such as $\beta$-carotene, ascorbate, thiols, and vitamin $\mathrm{E}$ with ferryl myoglobin has been the subject of various studies [7]. The reduction rates are mostly not very large [13]. For instance, the rate constant for the reaction of $\mathrm{MbFe}^{\mathrm{IV}}=\mathrm{O}$ with ascorbate (present in micromolar concentrations in several cells) is $2.7 \pm 0.8 \mathrm{M}^{-1} \mathrm{~s}^{-1}$ at $\mathrm{pH} 7.0$ and $25^{\circ} \mathrm{C}$ [13]. However, it has been proposed that the presence of these oneelectron reductants may be essential to avoid the accumulation of $\mathrm{MbFe}^{\mathrm{IV}}=\mathrm{O}$ and thus to prevent cell damage in reperfused tissues.

It has repeatedly been reported that also NO (nitrogen monoxide, nitric oxide) may act as an antioxidant and inhibit $\mathrm{MbFe}^{\mathrm{IV}}=\mathrm{O}$-induced oxidative damage $[3,14,15,16,17,18,19]$. Indeed, NO can reduce $\mathrm{MbFe}^{\mathrm{IV}}=\mathrm{O}$ to metMb $[14,16]$, modulate $\mathrm{MbFe}^{\mathrm{IV}}=\mathrm{O}-$ mediated oxidation of low-density lipoproteins [14], and inhibit $\mathrm{MbFe}^{\mathrm{IV}}=\mathrm{O}$-catalyzed oxidation reactions [16]. Despite the physiological importance attributed to the reaction between $\mathrm{NO}$ and $\mathrm{MbFe}^{\mathrm{IV}}=\mathrm{O}$, its rate constant has never been determined. This information is indispensable in order to evaluate the relevance of this reaction in vivo.

As nitrite is one of the major end products of NO metabolism, its local concentration reflects that of NO. Increased nitrite levels are thus found under pathophysiological conditions such as inflammation, when NO production is elevated. For instance, high levels of nitrite have been found in synovial fluids of patients with rheumatoid arthritis [20] and nitrite concentrations as high as $36 \mu \mathrm{M}$ have been measured in human serum of immunodeficiency virus-infected patients with interstitial pneumonia [21].

In contrast to the protective properties of $\mathrm{NO}^{\circ}$ against $\mathrm{H}_{2} \mathrm{O}_{2}$-mediated tissue injuries, nitrite dramatically enhances $\mathrm{H}_{2} \mathrm{O}_{2}$ toxicity, in particular in the presence of hemoproteins [22]. It has been suggested that the increased toxicity is due to the formation of nitrogen dioxide from the reaction of nitrite with the ferryl form of proteins such as myoglobin and peroxidases. Nitrogen dioxide is a toxic substance known to react with thiols [23], to cause lipid peroxidation [17, $24]$, and to damage DNA [17, 22]. Moreover, the peroxidase-catalyzed oxidation of nitrite has been proposed to represent an alternative source of tyrosine nitration [25]. In addition to the peroxynitrite-mediated nitration $[26,27,28]$, it may contribute to cell and tissue injury under conditions of increased NO production. The biological significance of tyrosine nitration is a subject of great interest, because extensive evidence supports the formation of nitrotyrosine in vivo in diverse pathological conditions (for review see [28]).
In this paper we present detailed kinetic and mechanistic studies on the reactions of $\mathrm{MbFe}^{\mathrm{IV}}=\mathrm{O}$ with $\mathrm{NO}^{\circ}$ and with nitrite. The rate constant determined for the $\mathrm{NO}$-mediated reduction of $\mathrm{MbFe}^{\mathrm{IV}}=\mathrm{O}$ is very large, $(17.9 \pm 0.5) \times 10^{6} \mathrm{M}^{-1} \mathrm{~s}^{-1}$ at $\mathrm{pH} 7.5$ and $20^{\circ} \mathrm{C}$. Thus, we conclude that this reaction is very likely to represent a plausible route for inhibition of $\mathrm{MbFe}^{\mathrm{IV}}=\mathrm{O}$-mediated oxidative damage. In contrast, the reaction between nitrite and $\mathrm{MbFe}^{\mathrm{IV}}=\mathrm{O}$ is relatively slow, $16 \pm 1 \mathrm{M}^{-1} \mathrm{~s}^{-1}$ at $\mathrm{pH} 7.5$ and $20^{\circ} \mathrm{C}$. This reaction probably plays a role only when $\mathrm{NO}^{\circ}$ has been completely depleted and no peroxynitrite is present. The results reported are important for a better understanding of the interaction of $\mathrm{NO}^{\text {with }}$ hemoproteins with oxidase activity under inflammatory or ischemic conditions, when generation of both $\mathrm{NO}$ and $\mathrm{H}_{2} \mathrm{O}_{2}$ is elevated.

\section{Materials and methods}

Reagents

Buffer solutions were prepared from $\mathrm{K}_{2} \mathrm{HPO}_{4} / \mathrm{KH}_{2} \mathrm{PO}_{4}$ (Fluka) or from $\mathrm{Na}_{2} \mathrm{~B}_{4} \mathrm{O}_{7} .10 \mathrm{H}_{2} \mathrm{O} / \mathrm{NaOH}$ (Fluka) with deionized Milli-Q water. Sodium nitrite, sodium nitrate, and hydrogen peroxide were supplied from Fluka. Catalase (bovine liver, 17,000 units/mg protein) was obtained from Sigma.

Nitrogen monoxide was obtained from Linde and passed through a degassed $\mathrm{NaOH}$ solution as well as a column of $\mathrm{NaOH}$ pellets to remove higher nitrogen oxides before use. A saturated NO solution was prepared by degassing water for 45 min with $\mathrm{N}_{2}$ and then saturating it with NO. The obtained stock solution (ca. $2 \mathrm{mM}$ ) was diluted with degassed buffer in gas-tight SampleLock Hamilton syringes. The final NO concentrations were measured with an ANTEK Instruments nitrogen monoxide analyzer, with a chemiluminescent detector.

Horse heart metmyoglobin was purchased from Sigma and purified over a Sephadex G-25 column. The concentration of $\mathrm{H}_{2} \mathrm{O}_{2}$ was determined spectrophotometrically at $240 \mathrm{~nm}$ $\left(\varepsilon_{240}=39.4 \mathrm{M}^{-1} \mathrm{~cm}^{-1}\right)$ [29]. $\mathrm{MbFe}^{\mathrm{IV}}=\mathrm{O}$ was prepared by adding 7-15 equiv of $\mathrm{H}_{2} \mathrm{O}_{2}$ to a metMb solution at room temperature. After a reaction time of 5-20 min, depending on the $\mathrm{pH}$, the $\mathrm{MbFe}^{\mathrm{IV}}=\mathrm{O}$ solutions were stored on ice and used within $1 \mathrm{~h}$. In some cases, catalase was added prior to reaction with $\mathrm{NO}$ to destroy excess $\mathrm{H}_{2} \mathrm{O}_{2}$. However, this procedure proved not to be necessary as identical kinetic results were obtained with or without addition of catalase. The concentration of the metMb solutions was determined by measuring the absorbances at 408, 502, and $630 \mathrm{~nm} \quad\left(\varepsilon_{408}=188 \mathrm{mM}^{-1} \mathrm{~cm}^{-1}, \quad \varepsilon_{502}=10.2 \mathrm{mM}^{-1} \mathrm{~cm}^{-1}\right.$, and $\left.\varepsilon_{630}=3.9 \mathrm{mM}^{-1} \mathrm{~cm}^{-1}\right)$ at neutral $\mathrm{pH}$ as well as at acidic $\mathrm{pH}$, and at 411,539 , and $585 \mathrm{~nm}\left(\varepsilon_{411}=119 \mathrm{mM}^{-1} \mathrm{~cm}^{-1}, \varepsilon_{539}=8.8 \mathrm{mM}^{-1} \mathrm{~cm}^{-1}\right.$, and $\varepsilon_{585}=7.8 \mathrm{mM}^{-1} \mathrm{~cm}^{-1}$ ) at $\mathrm{pH} 9.5$ [30]. The concentrations of the $\mathrm{MbFe}^{\mathrm{IV}}=\mathrm{O}$ solutions were determined by measuring the absorbance at $421 \mathrm{~nm}\left(\varepsilon_{421}=111 \mathrm{mM}^{-1} \mathrm{~cm}^{-1}\right)$ [31].

\section{Stopped-flow kinetic analysis}

Kinetic studies were carried out with an On-Line Instrument System stopped flow instrument equipped with an OLIS RSM 1000 rapid scanning monochromator and with an Applied Photophysics SX17MV single-wavelength stopped-flow instrument. The pathlengths of the cells in the two spectrophotometers were 2 and $1 \mathrm{~cm}$, respectively. With the Applied Photophysics apparatus, kinetic traces were taken at different wavelengths between 400 and $635 \mathrm{~nm}$ and the data were analyzed with the SX17MV 
operating software or with Kaleidagraph, version 3.0.5. Traces (averages of at least 10 single traces) from at least five experiments were averaged to obtain each observed rate constant, given with the corresponding standard error. Care was taken that the absolute absorbance of the reaction mixture was not higher than one absorbance unit.

For the measurements between $\mathrm{pH} 6.5$ and 9.5 the $\mathrm{MbFe}^{\mathrm{IV}}=\mathrm{O}$ and NO solutions were both prepared in $0.1 \mathrm{M}$ buffers of the required $\mathrm{pH}$ value. Measurements at $\mathrm{pH} 5.9$ were carried out by mixing a $\mathrm{MbFe}^{\mathrm{IV}}=\mathrm{O}$ solution prepared in a $0.1 \mathrm{M}$ phosphate buffer at $\mathrm{pH} 6.5$ with a NO solution at $\mathrm{pH} 4.0$. The $\mathrm{pH}$ was measured at the end of the reactions for control.

\section{UV-visible spectra}

UV-visible spectra were collected on a UVIKON 820 spectrophotometer. To determine the yield of the reaction between $\mathrm{NO}$ and $\mathrm{MbFe}^{\mathrm{IV}}=\mathrm{O}$, spectra were measured in sealable cells for anaerobic applications. About $3 \mathrm{~mL}$ of a $100 \mu \mathrm{M}$ metMb solution were placed in the cell and mixed with ca. 3 equiv of $\mathrm{H}_{2} \mathrm{O}_{2}$ $\left(100 \mu \mathrm{L}\right.$ of a $0.01 \mathrm{M}$ solution). When the $\mathrm{MbFe}^{\mathrm{IV}}=\mathrm{O}$ had completely formed the cell was sealed and about $150 \mu \mathrm{L}$ of $\mathrm{NO}^{-}$-saturated solution were added.

\section{Ion chromatographic product analysis}

Product analysis was carried out by anion chromatography with conductivity detection with a Metrohm Instrument (ICSeparation Center 733, ICDetector 732, and IC pump 709) equipped with an Anion SUPER-SEP (6.1009.000) column and an Anion SUPER-SEP (6.1009.010) precolumn as described previously [32]. A phthalic acid solution $(2.5 \mathrm{mM}$ phthalic acid, $5 \%$ acetonitrile, $\mathrm{pH} 4.2$, Tris) was used as eluent. Calibration curves were obtained by measuring 5-10 standard sodium nitrite and sodium nitrate solutions in $1 \mathrm{mM}$ sodium phosphate buffer.

The protein samples were prepared by adding 7-15 equiv $\mathrm{H}_{2} \mathrm{O}_{2}$ to $20 \mathrm{~mL}$ of a metMb solution $(25-50 \mu \mathrm{M}$ in $2 \mathrm{mM}$ phosphate or $1 \mathrm{mM}$ borate buffer). After a reaction time of 5-20 min, that is when the UV-visible spectrum indicated that $\mathrm{MbFe}^{\mathrm{IV}}=\mathrm{O}$ had been formed completely, excess $\mathrm{H}_{2} \mathrm{O}_{2}$ was destroyed by addition of about $100 \mu \mathrm{L}$ of a solution of catalase in water $(1 \mathrm{mg} / \mathrm{mL})$. After $10 \mathrm{~min}$ the solution was placed in a $20 \mathrm{~mL}$ Schlenk flask, sealed with a rubber septum, and the required amount of NO $(250-500 \mu \mathrm{L}$ of a saturated $2 \mathrm{mM}$ NO solution) was added with a gas-tight Hamilton syringe under constant stirring. A long needle was used in order to add the NO solution at the bottom of the flask to avoid any contact of NO with the oxygen present in the head space of the flask. After about 5 min the reaction mixture was diluted with buffer and analyzed. The amount of contaminating nitrite and nitrate present in the NO solution was determined prior to each experiment by injecting $1 \mathrm{~mL}$ of the saturated $\mathrm{NO}$ solution with a gas-tight syringe into $9 \mathrm{~mL}$ of $\mathrm{O}_{2}$-saturated water placed in a sealed $10 \mathrm{~mL}$ Schlenk flask. After stirring for about $10 \mathrm{~min}$ the reaction mixture was diluted and analyzed. With this procedure, nitrite is quantitatively formed from the reaction of $\mathrm{NO}^{-}$with $\mathrm{O}_{2}$ in water. Thus, the amount of nitrite found in excess relative to the NO used for these experiments corresponded to the amount of nitrite already present in the NO solution. In some cases also nitrate was found as a contaminant and probably derived from oxygen impurities in the apparatus. The protein samples of the reactions with nitrite were prepared analogously by adding $100-200 \mu \mathrm{L}$ of a $40-60 \mathrm{mM}$ sodium nitrite solution in $0.1 \mathrm{M}$ phosphate buffer.
Analysis of the free nitrotyrosine content generated by the reaction of nitrite with ferryl myoglobin in the presence of added free tyrosine

$\mathrm{MbFe}^{\mathrm{IV}}=\mathrm{O}$, prepared by mixing $1.5 \mathrm{~mL}$ of a $295 \mu \mathrm{M}$ metMb solution with one equivalent of $\mathrm{H}_{2} \mathrm{O}_{2}(44 \mu \mathrm{L}$ of a $0.01 \mathrm{M}$ solution), was allowed to react with a solution containing 4 equiv of tyrosine and different amounts of nitrite (between 4 and 50 equiv). The final solution, which contained $250 \mu \mathrm{M}$ protein, was analyzed by HPLC (see Table 6 below, entries 1-3) with a Hewlett Packard Series 1050 apparatus with a Series $1100 \mathrm{UV} /$ Vis-Detector, equipped with a VYDAC 218TP54 Protein\&Peptide C18-Column $(250 \times 4.6 \mathrm{~mm})$. Solvent $\mathrm{A}$ was $0.07 \%$ TFA in $\mathrm{H}_{2} \mathrm{O}$ and solvent $\mathrm{B}$ was $0.07 \%$ TFA in acetonitrile. Nitrotyrosine $\left(\mathrm{NO}_{2}\right.$-Tyr) was eluted (ca. $8 \mathrm{~min}$ after injection) by keeping the amount of $\mathrm{B}$ constant $(5 \%)$ in the first $2 \mathrm{~min}$ and then by using an increasing linear gradient of B from 5 to $10 \%$ between 2 and $10 \mathrm{~min}$, and from 10 to $80 \%$ between 10 and $15 \mathrm{~min} . \mathrm{NO}_{2}-\mathrm{Tyr}$ was detected contemporaneously at 220, 280, 350, and $400 \mathrm{~nm}$ and was quantified by measuring a calibration curve of 5-10 $\mathrm{NO}_{2}$-Tyr standard solutions.

Alternatively, reactions were carried out by mixing $1.5 \mathrm{~mL}$ of a $295 \mu \mathrm{M}$ metMb solution containing 4 equiv of tyrosine and different amounts of nitrite (between 4 and 50 equiv) with a solution containing 1 equiv of $\mathrm{H}_{2} \mathrm{O}_{2}$ (relative to the protein). The resulting protein solution, which contained $250 \mu \mathrm{M}$ protein, was analyzed by HPLC as described above (see Table 6 below, entries 4-7).

Analysis of the nitrotyrosine content after reaction of ferryl myoglobin with $\mathrm{NO}^{\circ}$ and nitrite

A $\mathrm{MbFe}^{\mathrm{IV}}=\mathrm{O}$ solution in $0.1 \mathrm{M}$ phosphate buffer, $\mathrm{pH}$ 7.0, was prepared by adding 1 equiv of $\mathrm{H}_{2} \mathrm{O}_{2}$ to metMb $(320 \mu \mathrm{M})$ [33, 34]. After $80 \mathrm{~s}$, the time needed for generation of $\mathrm{MbFe}^{\mathrm{IV}}=\mathrm{O}$, different amounts of NO ( 0.1 or 0.5 equiv) were added under stirring. When the reaction was complete (in less than $1 \mathrm{~min}$ ), nitrite was removed by washing the solution through a 10,000 MW cut-off filter (Centriplus YM-10, Amicon, Switzerland) at $3000 \mathrm{~g}$ until the ultrafiltrate did not show any qualitative reaction (pink coloring) with the Griess reagent [35]. The resulting protein was hydrolyzed by treating it $(0.5 \mathrm{~mL}$ of a $320 \mu \mathrm{M}$ solution) for $24 \mathrm{~h}$ with $0.3 \mathrm{~mL} 6 \mathrm{M} \mathrm{HCl}$ at $100^{\circ} \mathrm{C}$ in a closed vial. The solution was allowed to dry in air by maintaining the temperature at $100{ }^{\circ} \mathrm{C}$ and by opening the vial. The residual was redissolved in $50 \mu \mathrm{L} \mathrm{H}_{2} \mathrm{O}$ and analyzed by HPLC as described above.

The $\mathrm{NO}_{2}$-Tyr content in myoglobin after reaction of $\mathrm{MbFe}^{\mathrm{IV}}=\mathrm{O}$ with nitrite was measured analogously. $\mathrm{A} \mathrm{MbFe}^{\mathrm{IV}}=\mathrm{O}$ solution in $0.1 \mathrm{M}$ phosphate buffer, $\mathrm{pH} 7.0$, prepared by adding 2 equiv of $\mathrm{H}_{2} \mathrm{O}_{2}$ to a metMb solution $(160 \mu \mathrm{M})$, was allowed to react with nitrite (either 0.2 or 10 equiv). When the reaction was over (in less than $1 \mathrm{~min}$ ), nitrite was washed by centrifugation (see above), the resulting protein was hydrolyzed, and the amino acids were analyzed by HPLC as described above.

\section{Results}

Stopped-flow kinetic studies of the $\mathrm{NO}^{-}$-mediated reduction of ferryl myoglobin

The reaction between $\mathrm{NO}$ and $\mathrm{MbFe}^{\mathrm{IV}}=\mathrm{O}$ (horse heart) was studied by single-wavelength stopped-flow spectroscopy in the $\mathrm{pH}$ range $5.9-9.5$ at $20^{\circ} \mathrm{C}$. In order to avoid the difficulties associated with the accurate determination of the concentration of $\mathrm{NO}$ solutions during the measurements, the protein was present in 


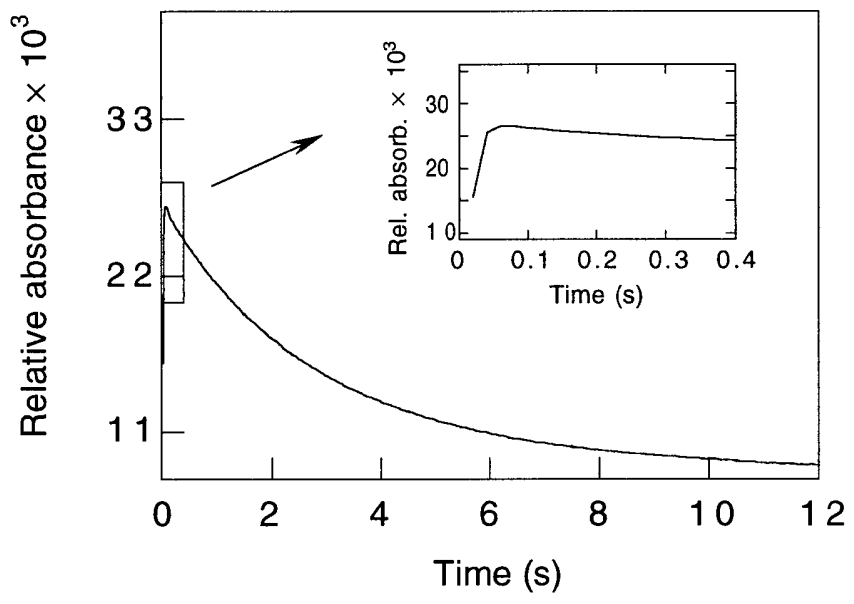

Fig. 1 Time course measured at $411 \mathrm{~nm}$ for the reaction of $\mathrm{MbFe}^{\mathrm{IV}}=\mathrm{O}(8.1 \mu \mathrm{M})$ with $\mathrm{NO}(0.9 \mu \mathrm{M})$ in $0.1 \mathrm{M}$ borate buffer at $\mathrm{pH} 9.5$ and $20^{\circ} \mathrm{C}$

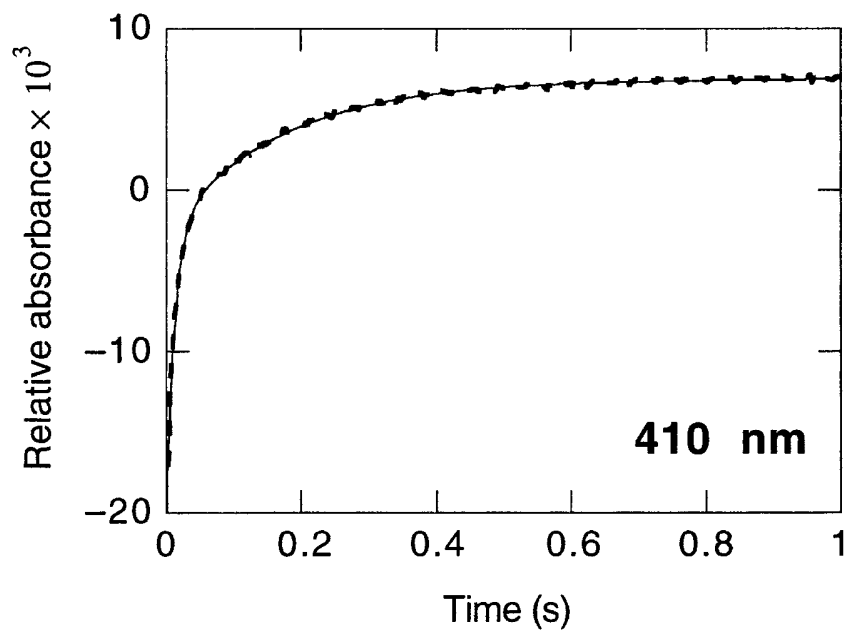

Fig. 2 Time course measured at $410 \mathrm{~nm}$ for the reaction of $\mathrm{MbFe}^{\mathrm{IV}}=\mathrm{O}(4.7 \mu \mathrm{M})$ with $\mathrm{NO}(0.6 \mu \mathrm{M})$ in $0.1 \mathrm{M}$ phosphate buffer at $\mathrm{pH} 7.0$ and $20^{\circ} \mathrm{C}$. The solid line corresponds to the best fit for the formation and the decay of the intermediate $\mathrm{MbFe}^{\mathrm{III}} \mathrm{ONO}$. The resulting rate constants are $k_{1, \mathrm{obs}}=80 \pm 1 \mathrm{~s}^{-1}$ and $k_{2, \mathrm{obs}}=5.80 \pm 0.05 \mathrm{~s}^{-1}$, respectively

8- to 10-fold excess to maintain pseudo-first-order conditions. The kinetic traces were measured by following the absorbance changes at several wavelengths in the Soret region. Over the entire $\mathrm{pH}$ range studied the reaction proceeds via an intermediate that decays to the final product metMb. As depicted in Fig. 1, the kinetic trace collected at $\mathrm{pH} 9.5$ at $411 \mathrm{~nm}$ clearly shows a rapid increase in the absorbance followed by a slower decrease. At $\mathrm{pH} 7.0$ the trace measured at $410 \mathrm{~nm}$ shows a biphasic increase in absorbance which could be fitted well to two single-exponential expressions (Fig. 2). In both cases the two reactions correspond to the formation of the intermediate and its subsequent decay. The second-order rate constants $\left(k_{1}\right)$ for the formation of the intermediate, obtained

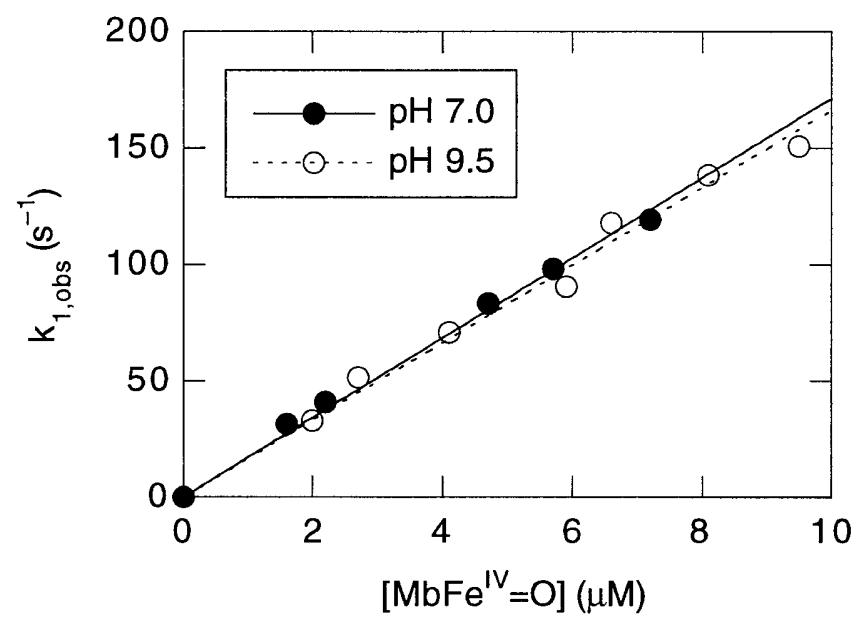

Fig. 3 Plots of $k_{1, \text { obs }}$ versus $\mathrm{MbFe} \mathrm{IV}^{\mathrm{IV}}=\mathrm{O}$ concentration for the formation of the intermediate $\mathrm{MbFe}{ }^{\mathrm{III}} \mathrm{ONO}$ from the reaction of $\mathrm{MbFe}^{\mathrm{IV}}=\mathrm{O}$ with $\mathrm{NO}$ at $\mathrm{pH} 7.0$ and $9.5\left(20^{\circ} \mathrm{C}\right)$. The values of the second-order rate constants obtained from the linear fits are given in Table 1

from the linear plots of the observed pseudo-first-order rate constants versus $\mathrm{MbFe}^{\mathrm{IV}}=\mathrm{O}$ concentration (Fig. 3), did not change significantly in the $\mathrm{pH}$ range studied (Fig. 3 and Table 1). At pH 7.5 we obtained $k_{1}=(17.9 \pm 0.5) \times 10^{6} \mathrm{M}^{-1} \mathrm{~s}^{-1}$ for the $\mathrm{NO}$-mediated reduction of $\mathrm{MbFe}^{\mathrm{IV}}=\mathrm{O}$. The same value for the second-order rate constant was obtained when the reaction was studied with $\mathrm{NO}^{-}$as the reagent used in 10-fold excess. Moreover, the same rate constant was also found when $\mathrm{MbFe}^{\mathrm{IV}}=\mathrm{O}$ was prepared at $\mathrm{pH} 8.5$ and then mixed with a $\mathrm{pH} 6.5$ solution of $\mathrm{NO}^{-}$to yield a final $\mathrm{pH}$ of 7.0. Alkaline conditions are known to generate the lowest amount of side products in the course of the reaction between $\mathrm{MbFe}^{\mathrm{IV}}=\mathrm{O}$ and $\mathrm{H}_{2} \mathrm{O}_{2}[36,37]$.

As expected, the rate constant for the decay of the intermediate to metMb $\left(k_{2}\right)$, measured within a broad range of $\mathrm{NO}$ and $\mathrm{MbFe}^{\mathrm{IV}}=\mathrm{O}$ concentrations, was independent from the $\mathrm{NO}^{\circ}$ as well as the $\mathrm{MbFe}^{\mathrm{IV}}=\mathrm{O}$ concentrations. Moreover, the same rate constant was obtained when either of the two reagents was used in excess. When NO was used in large excess, an additional reaction was observed on a longer time scale which corresponded to $\mathrm{NO}$ binding to the product metMb. The rate of decay of $\mathrm{MbFe}^{\mathrm{III}} \mathrm{ONO}$ is highly

Table $1 \mathrm{pH}$ dependencies of the second-order rate constants for the formation $\left(k_{1}\right)$ of the intermediate $\mathrm{MbFe} \mathrm{III}^{\mathrm{II}} \mathrm{ONO}$ and of the observed rate constants for its decay $\left(k_{2}\right)$ to metMb at $20^{\circ} \mathrm{C}$

\begin{tabular}{lll}
\hline $\mathrm{pH}$ & $k_{1}\left(\mu \mathrm{M}^{-1} \mathrm{~s}^{-1}\right)$ & $k_{2}\left(\mathrm{~s}^{-1}\right)$ \\
\hline 5.9 & $17.0 \pm 0.5$ & $21.0 \pm 0.9$ \\
6.5 & $18.7 \pm 0.2$ & $10.8 \pm 0.3$ \\
7.0 & $17.1 \pm 0.3$ & $5.98 \pm 0.06$ \\
7.5 & $17.9 \pm 0.5$ & $3.36 \pm 0.05$ \\
8.5 & $19.5 \pm 0.1$ & $1.26 \pm 0.03$ \\
9.5 & $16.6 \pm 0.4$ & $0.347 \pm 0.006$ \\
\hline
\end{tabular}




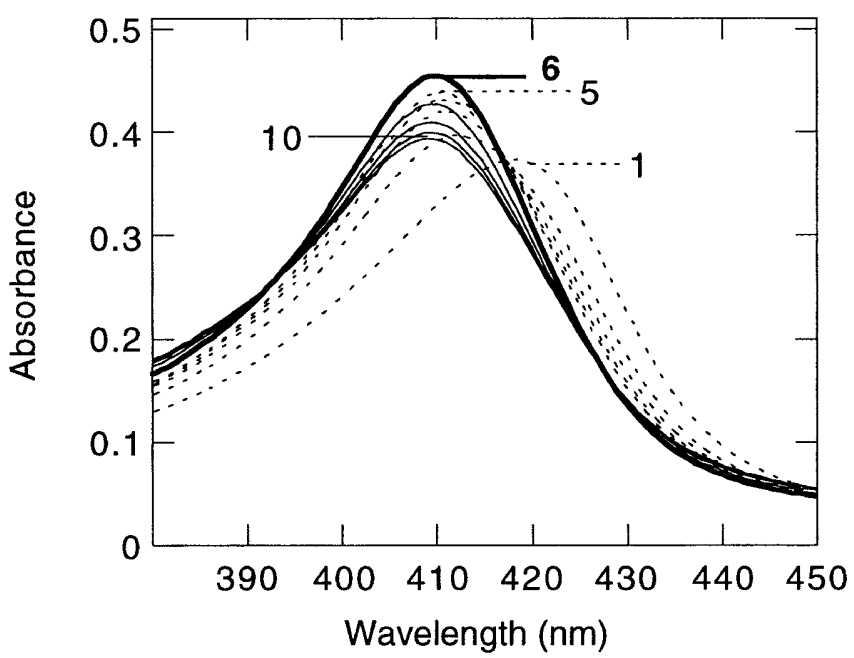

Fig. 4 Rapid-scan UV-visible spectra of the reaction of $\mathrm{MbFe}^{\mathrm{IV}}=\mathrm{O}(3.7 \mu \mathrm{M})$ with $\mathrm{NO}(4.7 \mu \mathrm{M})$ in $0.1 \mathrm{M}$ borate buffer at $\mathrm{pH} 9.5$ and $20^{\circ} \mathrm{C}$. The formation of the intermediate $\mathrm{MbFe}^{\mathrm{III}} \mathrm{ONO}$ (trace 6) from $\mathrm{MbFe}^{\mathrm{IV}}=\mathrm{O}$ (dashed traces 1-5) and its decay to metMb (traces $6-10$ ) are presented. Time intervals of the shown spectra are: traces $1-5$, every $16 \mathrm{~ms}$; trace 6 , after $320 \mathrm{~ms}$; traces $7-9$, every $1.6 \mathrm{~s}$; and trace 10 , after a total of $9.84 \mathrm{~s}$

$\mathrm{pH}$ dependent and increases with decreasing $\mathrm{pH}$ (Table 1). At pH 7.5 we obtained $k_{2}=3.36 \pm 0.05 \mathrm{~s}^{-1}$ for the rate of decay of the intermediate to metMb.

Spectral characterization of the nitrito intermediate $\mathrm{MbFe} \mathrm{III}^{\mathrm{IIINO}}$

The $\mathrm{NO}$-mediated reduction of $\mathrm{MbFe}^{\mathrm{IV}}=\mathrm{O}$ to metMb was studied by rapid-scan UV-visible spectroscopy between 380 and $680 \mathrm{~nm}$ at $\mathrm{pH} 9.5$ and $20^{\circ} \mathrm{C}$. As shown in Fig. 4, the Soret band of myoglobin shifted from $421 \mathrm{~nm}\left(\mathrm{MbFe}^{\mathrm{IV}}=\mathrm{O}\right.$, spectrum 1) to $411 \mathrm{~nm}$ (metMb at $\mathrm{pH} 9.5$, spectrum 10) via an intermediate species with an absorption maximum at $410 \mathrm{~nm}$ and an extinction coefficient of about $137 \mathrm{mM}^{-1} \mathrm{~cm}^{-1}$ (spectrum 6 in Fig. 4). The best spectrum obtained for the intermediate in the visible region is shown as the first trace in Fig. 5. As higher concentrations were used to reduce the signal-to-noise ratio, accumulation of the intermediate occurred within the dead time of the instrument. Two characteristic absorption maxima were found at $631 \mathrm{~nm} \quad\left(\varepsilon_{631}=5.1 \mathrm{mM}^{-1} \mathrm{~cm}^{-1}\right)$ and $504 \mathrm{~nm}\left(\varepsilon_{504}=8.7 \mathrm{mM}^{-1} \mathrm{~cm}^{-1}\right)$. These maxima are very similar to those of the recently characterized peroxynitrito-methemoglobin complex (HbFe ${ }^{\mathrm{III}} \mathrm{OONO}$ ) [38] and are typical for high-spin metHb and metMb derivatives with anionic oxygen ligands such as carboxylates [30], nitrite [39], and nitrate (Table 2). We thus assign this species as the nitrito-metmyoglobin complex $\mathrm{MbFe}^{\mathrm{III}} \mathrm{ONO}$ (Scheme 1).

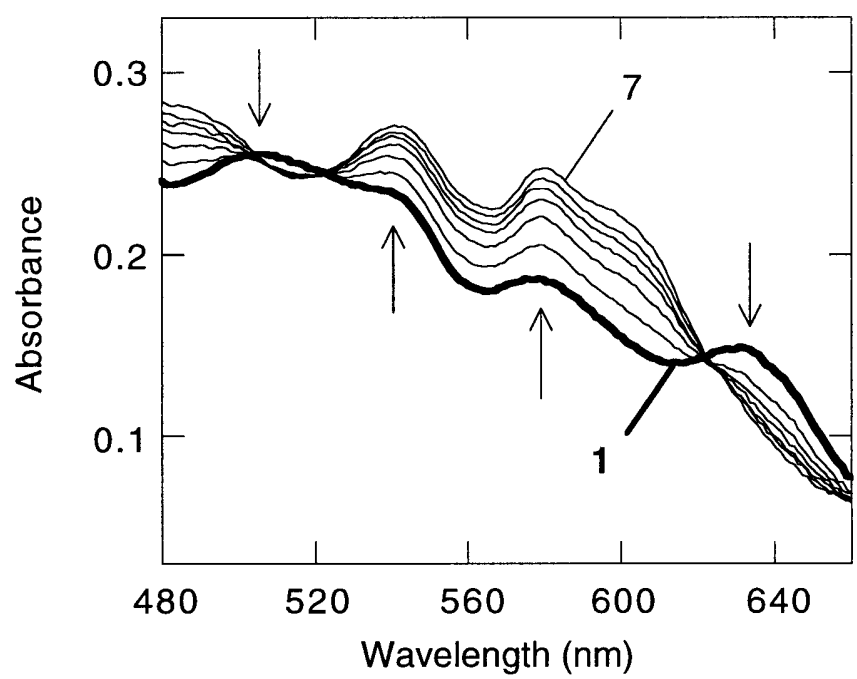

Fig. 5 Rapid-scan UV-visible spectra of the reaction of $\mathrm{MbFe}^{\mathrm{IV}}=\mathrm{O}(14.7 \mu \mathrm{M})$ with $\mathrm{NO}(50 \mu \mathrm{M})$ in $0.1 \mathrm{M}$ borate buffer at $\mathrm{pH} 9.5$ and $20^{\circ} \mathrm{C}$. The decay of the intermediate $\mathrm{MbFe}^{\mathrm{III}} \mathrm{ONO}$ to metMb is presented. Time intervals of the shown spectra are: traces $1-6$, every $400 \mathrm{~ms}$; trace $7,8 \mathrm{~s}$ later; for a total of $10 \mathrm{~s}$

Table 2 Spectroscopic data for metmyoglobin complexes

\begin{tabular}{lllll}
\hline & Soret & \multicolumn{2}{l}{ Visible } & \multirow{2}{*}{ Ref } \\
\cline { 3 - 4 } & $\lambda_{\max }(\varepsilon)^{\mathrm{a}}$ & $\lambda_{\max }(\varepsilon)^{\mathrm{a}}$ & $\lambda_{\max }(\varepsilon)^{\mathrm{a}}$ & \\
\hline $\mathrm{MbFe}^{\mathrm{III}} \mathrm{ONO}$ & $410(137)$ & $504(8.7)$ & $534 \mathrm{sh}$ & This work \\
$\mathrm{MbFe}^{\mathrm{III}} \mathrm{NO}_{2}$ & $412(137)$ & $575(6.3)$ & $631(5.1)$ & \\
& & $573(5.4)$ & $537 \mathrm{sh}$ & {$[58]$} \\
$\mathrm{MbFe}^{\mathrm{III}} \mathrm{ONO}_{2}$ & $404(172)$ & $502(8.8)$ & $629(4.2)$ & \\
$\mathrm{MbFe}^{\mathrm{III}} \mathrm{OONO}_{2}$ & $410(138)$ & $504(8)$ & $636(3.6)$ & {$[58]$} \\
$\mathrm{MbFe}^{\mathrm{III}} \mathrm{OH}_{2}$ & $408(188)$ & $502(10.2)$ & $630(3.9)$ & {$[30]$} \\
\hline
\end{tabular}

${ }^{\mathrm{a}} \lambda_{\max }$ in $\mathrm{nm} ; \varepsilon$ in $\mathrm{mM}^{-1} \mathrm{~cm}^{-1}$

UV-visible spectra of the protein product and yield of the reaction

In order to determine the stoichiometry of the reaction of $\mathrm{NO}$ with $\mathrm{MbFe}^{\mathrm{IV}}=\mathrm{O}$ and the purity of the metMb formed, the reaction products were analyzed by UV-visible spectroscopy. As shown in Fig. 6, when about one equivalent of NO was mixed with $\mathrm{MbFe}^{\mathrm{IV}}=\mathrm{O}$ at $\mathrm{pH} 7.0$ a species was formed (spectrum C) with an absorbance spectrum similar but not identical to that of metMb (spectrum A). In particular, a new absorbance band with a maximum around $590 \mathrm{~nm}$ appeared and the band at $630 \mathrm{~nm}$ was modified as well. However, when a $\mathrm{MbFe}^{\mathrm{IV}}=\mathrm{O}$ solution was allowed to decay back to metMb, a very similar altered spectrum was obtained (spectrum D in Fig. 6) (as in [40]). The new absorbance band at $590 \mathrm{~nm}$ is 


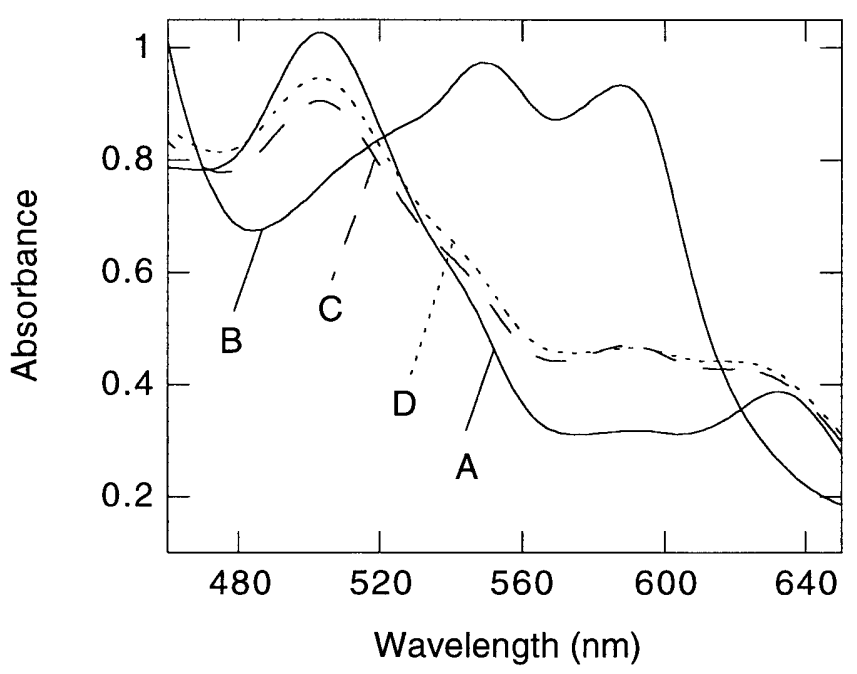

Fig. $6 \mathrm{UV}$-visible spectra in $0.1 \mathrm{M}$ phosphate buffer at $\mathrm{pH}$ 7.0. $A \mathrm{MbFe}^{\mathrm{III}} \mathrm{OH}_{2}(100 \mu \mathrm{M}) ; B \mathrm{MbFe}^{\mathrm{IV}}=\mathrm{O}(100 \mu \mathrm{M}) ; C \mathrm{MbFe}^{\mathrm{IV}}=\mathrm{O}$ $(100 \mu \mathrm{M}) \mathrm{NO}^{\prime}(110 \mu \mathrm{M}) ; D \mathrm{MbFe}^{\mathrm{IV}}=\mathrm{O}(100 \mu \mathrm{M})$ decayed to $\mathrm{MbFe}^{\mathrm{III}} \mathrm{OH}_{2}$ after ca. $2.5 \mathrm{~h}$

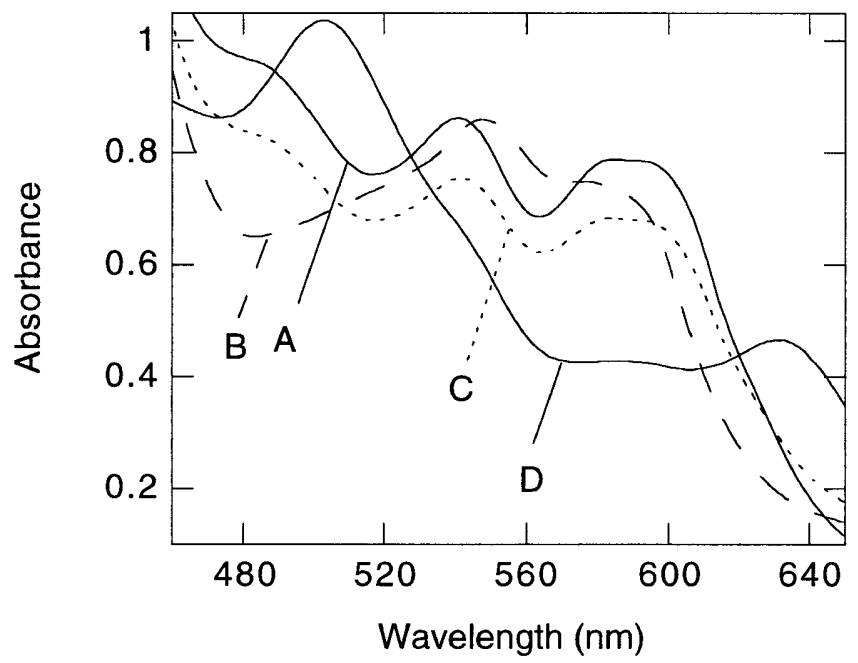

Fig. $7 \mathrm{UV}$-visible spectra in $0.1 \mathrm{M}$ borate buffer at $\mathrm{pH}$ 9.5. $A$ $\mathrm{MbFe}{ }^{\mathrm{III}} \mathrm{OH}(100 \mu \mathrm{M}) ; B \quad \mathrm{MbFe}^{\mathrm{IV}}=\mathrm{O}(100 \mu \mathrm{M}) ; C \quad \mathrm{MbFe}^{\mathrm{IV}}=\mathrm{O}$ $(100 \mu \mathrm{M})$ NO $(110 \mu \mathrm{M}) ; D$ spectrum $\mathrm{C}$ at $\mathrm{pH} 7.0$

characteristic for a heme-protein cross-linked form. This species is known to be partly generated in the course of the reaction of $\mathrm{H}_{2} \mathrm{O}_{2}$ with metMb under acidic as well as neutral conditions [41] and is thus already present in the $\mathrm{MbFe}^{\mathrm{IV}}=\mathrm{O}$ solution.

It has previously been shown $[36,37]$ that the reaction between metMb and $\mathrm{H}_{2} \mathrm{O}_{2}$ proceeds with the minimum amount of side reactions between $\mathrm{pH} 8.0$ and 9.0. $\mathrm{MbFe}^{\mathrm{IV}}=\mathrm{O}$ was thus generated by mixing metMb and $\mathrm{H}_{2} \mathrm{O}_{2}$ at $\mathrm{pH}$ 8.5. When this solution was allowed to react with one equivalent of solution of $\mathrm{NO}^{\circ}$ at $\mathrm{pH} 6.5$, the spectrum of the product obtained at a final $\mathrm{pH}$ of 7.0 was identical to that of metMb (data not shown). Furthermore, as shown in Fig. 7, when about one equivalent of $\mathrm{NO}$ was mixed with $\mathrm{MbFe}^{\mathrm{IV}}=\mathrm{O}$ at $\mathrm{pH} 9.5$, a species was formed (spectrum C) with an absorbance spectrum almost identical to that of metMb under the same conditions (spectrum A). When this reaction solution was neutralized to $\mathrm{pH} 7.0$ the new spectrum (spectrum D in Fig. 7) was identical to that of metMb at $\mathrm{pH} 7.0$ (spectrum $\mathrm{A}$ in Fig. 6).

\section{Reaction between $\mathrm{MbFe}^{\mathrm{IV}}=\mathrm{O}$ and $\mathrm{NO}$}

It has been reported that in concentrated solutions $(300 \mu \mathrm{M}$ to $1 \mathrm{mM})$ metMb reacts with equimolar amounts of $\mathrm{H}_{2} \mathrm{O}_{2}$ to yield a two-electron oxidized form with a radical on the protein $\left(\mathrm{MbFe}^{\mathrm{IV}}=\mathrm{O}\right)[33$, 34]. The radical in $\mathrm{MbFe}^{\mathrm{IV}}=\mathrm{O}$ is probably localized on a tyrosine and/or a tryptophan residue and is stable for several minutes [33, 34]. An attempt was thus made, by using the sequential stopped-flow technique, to study the reaction between $\mathrm{MbFe}^{\mathrm{IV}}=\mathrm{O}$ and $\mathrm{NO}$. In particular, we were interested to find out whether NO reacts with the oxoiron(IV) center or with the radical on the protein.

A $\mathrm{MbFe}^{\mathrm{IV}}=\mathrm{O}$ solution was first generated in the stopped-flow apparatus by premixing equimolar amounts of metMb and $\mathrm{H}_{2} \mathrm{O}_{2}$ (ca. $350 \mu \mathrm{M}$ ). After a delay time between 10 and $500 \mathrm{~s}$ the $\mathrm{MbFe}^{\mathrm{IV}}=\mathrm{O}$ solution was mixed with a $\mathrm{NO}^{\prime}$ solution. The reaction was studied by following the absorbance changes at 540 and $590 \mathrm{~nm}$. Unfortunately, we could not obtain any useful information from the first $50 \mathrm{~ms}$ of the measured traces because of inhomogeneous mixing. This problem is often observed when highly concentrated viscous protein solutions are mixed in the stoppedflow apparatus. Thus, it was not possible to identify whether there was a difference in the absorbance changes arising from the reaction of $\mathrm{NO}^{-}$with $\mathrm{MbFe}^{\mathrm{IV}}=\mathrm{O}$ and those from the reaction with $\mathrm{MbFe}^{\mathrm{IV}}=\mathrm{O}$.

It has recently been shown that the reaction of NO with the tyrosyl radicals of prostaglandin $\mathrm{H}$ synthase [42], prostaglandin endoperoxide $\mathrm{H}$ synthase [43], and photosystem II $[44,45]$ generates nitrotyrosine. Therefore, we looked for nitrotyrosine in the protein after the reaction of $\mathrm{MbFe}^{\mathrm{IV}}=\mathrm{O}$ with NO . However, HPLC analysis of the amino acids obtained after complete acid hydrolysis indicated that no nitrotyrosine was generated (data not shown).

Stopped-flow kinetic studies of the nitrite-mediated reduction of ferryl myoglobin

The reaction between nitrite and $\mathrm{MbFe}^{\mathrm{IV}}=\mathrm{O}$ was studied by rapid-scan stopped-flow spectroscopy between 380 and $650 \mathrm{~nm}$. As shown in Fig. 8, when a large excess of nitrite was mixed with $\mathrm{MbFe} e^{\mathrm{IV}}=\mathrm{O}$ at $\mathrm{pH} 7.0$ the Soret band shifted from $421 \mathrm{~nm}\left(\mathrm{MbFe}^{\mathrm{IV}}=\mathrm{O}\right.$, spec- 


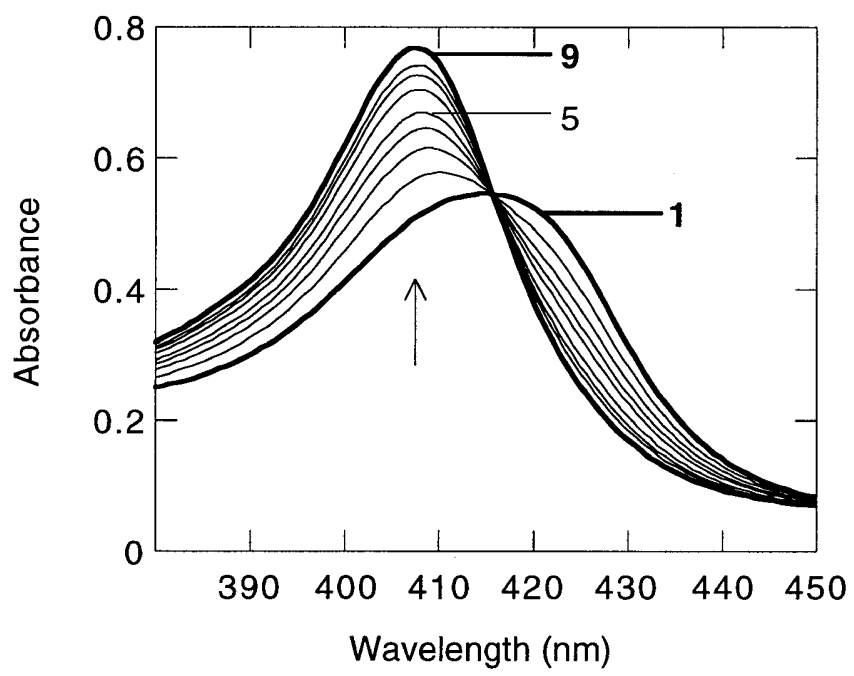

Fig. 8 Rapid-scan UV-visible spectra of the reaction of $\mathrm{MbFe}^{\mathrm{IV}}=\mathrm{O}(5.5 \mu \mathrm{M})$ with nitrite $(9.6 \mathrm{mM})$ in $0.1 \mathrm{M}$ phosphate buffer at $\mathrm{pH} 7.0$ and $20^{\circ} \mathrm{C}$. Time intervals of the shown spectra are: traces $1-5$, every $800 \mathrm{~ms}$; traces $6-8$, every $1.6 \mathrm{~s}$; trace 9 , after a total of $25.6 \mathrm{~s}$

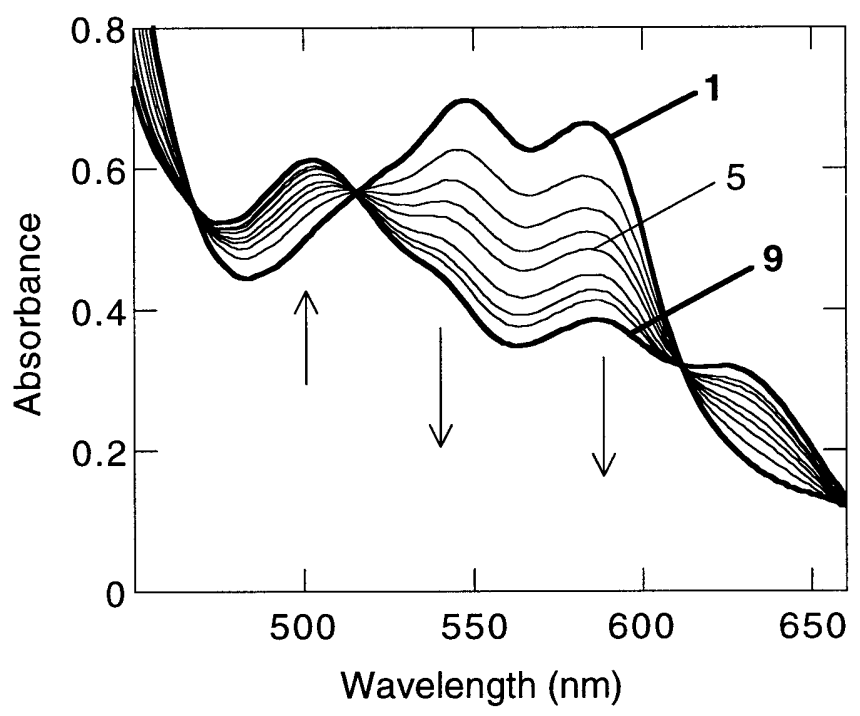

Fig. 9 Rapid-scan UV-visible spectra of the reaction of $\mathrm{MbFe}^{\mathrm{IV}}=\mathrm{O}(78 \mu \mathrm{M})$ with nitrite $(9.6 \mathrm{mM})$ in $0.1 \mathrm{M}$ phosphate buffer at $\mathrm{pH} 7.0$ and $20^{\circ} \mathrm{C}$. Time intervals of the shown spectra are: traces $1-5$, every $800 \mathrm{~ms}$; traces $6-8$, every $1.6 \mathrm{~s}$; trace 9 , after a total of $25.6 \mathrm{~s}$

trum 1) to $408 \mathrm{~nm}$ (metMb at $\mathrm{pH} 7.0$, spectrum 9). In addition, the two characteristic absorption maxima at 547 and $584 \mathrm{~nm}$ disappeared and the characteristic maxima for metMb at 502 and $630 \mathrm{~nm}$ appeared (Fig. 9). However, an additional band was observed at $586 \mathrm{~nm}$, that is at a slightly lower wavelength than that of the maximum arising from the cross-linked species generated during the synthesis of $\mathrm{MbFe}^{\mathrm{IV}}=\mathrm{O}$ (590 nm, see above). As $\mathrm{MbFe}^{\mathrm{III}} \mathrm{NO}_{2}$ has an absorbance maximum at $573 \mathrm{~nm}$ (Fig. 10), the new absorb-

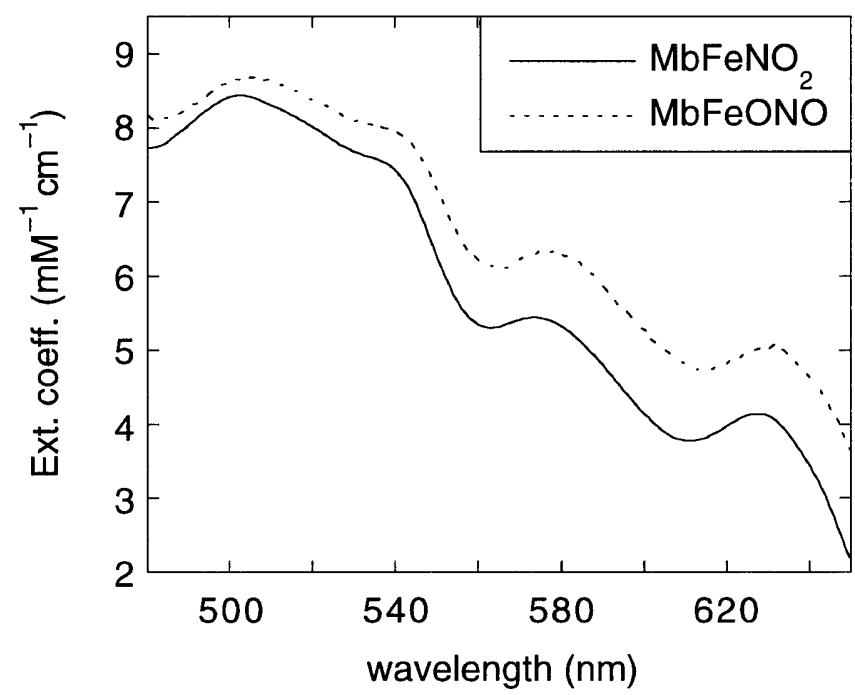

Fig. 10 Comparison of the UV-visible spectra of the intermediate $\mathrm{MbFe}{ }^{\mathrm{III}} \mathrm{ONO}$ and of $\mathrm{MbFe}^{\mathrm{III}} \mathrm{NO}_{2}$ in $0.1 \mathrm{M}$ phosphate buffer at $\mathrm{pH} 7.0$

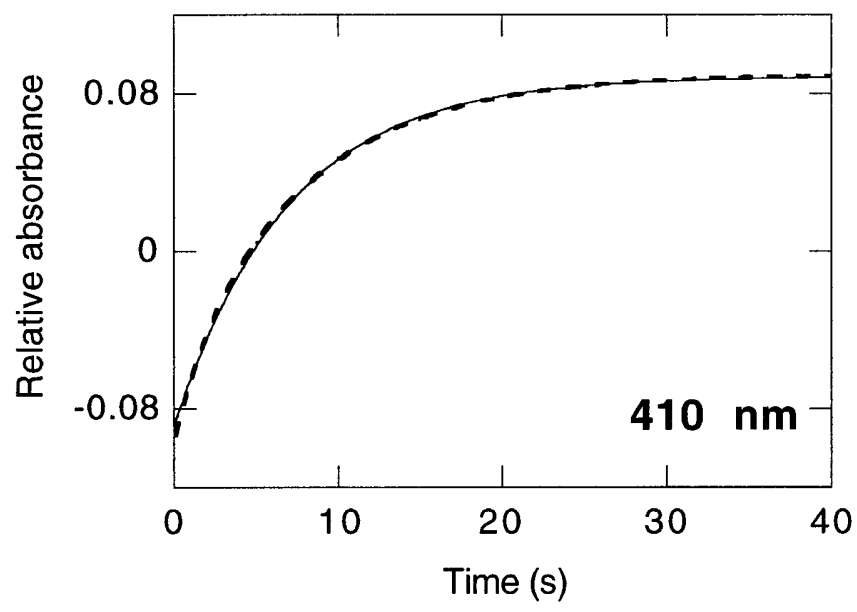

Fig. 11 Time course measured at $410 \mathrm{~nm}$ for the reaction of $\mathrm{MbFe}^{\mathrm{IV}}=\mathrm{O}(6 \mu \mathrm{M})$ with nitrite $(2.0 \mathrm{mM})$ in $0.1 \mathrm{M}$ phosphate buffer at $\mathrm{pH} 6.7$ and $20^{\circ} \mathrm{C}$. The solid line corresponds to the best fit, which results in the observed rate constant of $(14.4 \pm 0.1) \times 10^{-2} \mathrm{~s}^{-1}$

ance band at $586 \mathrm{~nm}$ suggests the formation of a mixture of metMb, the cross-linked species, and $\mathrm{MbFe}^{\mathrm{III}} \mathrm{NO}_{2}$.

Kinetic measurements were carried out by singlewavelength stopped-flow spectroscopy under pseudofirst-order conditions with nitrite in at least 10 -fold excess in the $\mathrm{pH}$ range $6.1-8.5$ at $20^{\circ} \mathrm{C}$. The kinetic traces, measured by following the absorbance increases at $410 \mathrm{~nm}$, could all be fitted well to a single-exponential expression (Fig. 11). The second-order rate constants $\left(k_{3}\right)$, obtained from the linear plots of the observed pseudo-first-order rate constants versus nitrite concentration (data not shown), are highly $\mathrm{pH}$ dependent (Table 3). At pH 6.1 we obtained $k_{3}=(3.7 \pm$ 
Table $3 \mathrm{pH}$ dependencies of the second-order rate constants for the reactions of nitrite with $\mathrm{MbFe}^{\mathrm{IV}}=\mathrm{O}\left(k_{3}\right)$ at $20^{\circ} \mathrm{C}$. $\mathrm{pH}$ dependencies of the association $\left(k_{4}\right)$ and dissociation $\left(k_{-4}\right)$ rates of the reaction of nitrite with metMb at $20^{\circ} \mathrm{C}$ together with the calculated equilibrium constants $\left(K_{4}\right)$

\begin{tabular}{lllll}
\hline $\mathrm{pH}$ & $k_{3}\left(\mathrm{M}^{-1} \mathrm{~s}^{-1}\right)$ & $k_{4}\left(\mathrm{M}^{-1} \mathrm{~s}^{-1}\right)$ & $k_{-4}\left(\mathrm{~s}^{-1}\right)$ & $K_{4}(\mathrm{M})$ \\
\hline 6.1 & $(3.7 \pm 0.4) \times 10^{2}$ & $(2.4 \pm 0.1) \times 10^{3}$ & $19 \pm 2$ & $(0.80 \pm 0.08) \times 10^{-2}$ \\
6.7 & $65 \pm 3$ & $(8.1 \pm 0.2) \times 10^{2}$ & $9.8 \pm 0.3$ & $(1.21 \pm 0.02) \times 10^{-2}$ \\
$7.0^{\mathrm{a}}$ & - & 470 & 6.4 & $1.36 \times 10^{-2}$ \\
7.5 & $16 \pm 1$ & $325 \pm 2$ & $4.0 \pm 0.2$ & $(1.23 \pm 0.06) \times 10^{-2}$ \\
$8.15^{\mathrm{a}}$ & - & 120 & 2.4 & $2.0 \times 10^{-2}$ \\
8.5 & $1.36 \pm 0.05$ & n.d. ${ }^{\mathrm{b}}$ & n.d. ${ }^{\mathrm{b}}$ & n.d. \\
$9.15^{\mathrm{a}}$ & - & 42 & 1.1 & $2.6 \times 10^{-2}$ \\
\hline
\end{tabular}

${ }^{\mathrm{a}} \operatorname{Ref}[30]$

${ }^{b}$ n.d. $=$ not determined
$0.4) \times 10^{2} \mathrm{M}^{-1} \mathrm{~s}^{-1}$. With increasing $\mathrm{pH}$ the second-order rate constant decreased continuously to $k_{3}=1.36 \pm$ $0.05 \mathrm{M}^{-1} \mathrm{~s}^{-1}$ at $\mathrm{pH}$ 8.5. The large error of the value at $\mathrm{pH} 6.1$ is due to the instability of the $\mathrm{MbFe}^{\mathrm{IV}}=\mathrm{O}$ solution under acidic conditions [46, 47, 48]. This instability did not cause any problems for the determination of the rate constant of the reaction with $\mathrm{NO}$ because this latter reaction proceeds at a significantly faster rate. In addition, at low $\mathrm{pH}$ and in the presence of a large excess of nitrite a second reaction was observed in the course of the stopped-flow measurements. The presence of this reaction, which corresponds to the subsequent binding of nitrite to metMb, also interfered with the exact determination of the rate constant of the reaction between nitrite and $\mathrm{MbFe}^{\mathrm{IV}}=\mathrm{O}$.

In order to be able to confirm that the second reaction observed was indeed that between nitrite and metMb, we determined its rate constant in an independent experiment under the same experimental conditions. The kinetics were studied by stopped-flow spectroscopy with nitrite in at least 10 -fold excess by following the absorbance changes at 410 or $575 \mathrm{~nm}$. The plot of the observed pseudo-first-order rate constant versus nitrite concentration showed a saturation behavior at nitrite concentrations above $100 \mathrm{mM}$ (data not shown). However, a second-order rate constant could be obtained from the linear part of the plots in the range 5-40 mM. As shown from the data summarized in Table 3, the binding rate of nitrite to metMb decreases with increasing $\mathrm{pH}$ and is always faster than the corresponding rate of reaction of nitrite with $\mathrm{MbFe}^{\mathrm{IV}}=\mathrm{O}$. At $\mathrm{pH} 6.7$ and $20^{\circ} \mathrm{C}$ the binding rate is $k_{4}=(8.1 \pm 0.2) \times 10^{2} \mathrm{M}^{-1} \mathrm{~s}^{-1}$, a value comparable to that reported in the literature $\left(4.7 \times 10^{2} \mathrm{M}^{-1} \mathrm{~s}^{-1}\right.$ at $\mathrm{pH} 7.0$ and $21-23{ }^{\circ} \mathrm{C}$ [30]). The dissociation rate, obtained from the intercept of the linear plot, is $k_{-4}=9.8 \pm 0.3 \mathrm{~s}^{-1}$ at $\mathrm{pH} 6.7$, and decreases with increasing $\mathrm{pH}$ (Table 3). This value is also in agreement with that reported in the literature $\left(6.4 \mathrm{~s}^{-1}\right.$ at $\mathrm{pH} 7.0$ and $\left.21-23^{\circ} \mathrm{C}[30]\right)$.

As the reaction of $\mathrm{MbFe}^{\mathrm{IV}}=\mathrm{O}$ with nitrite is very slow and the $\mathrm{MbFe}^{\mathrm{IV}}=\mathrm{O}$ solutions are not indefinitely stable [46, 47, 48], it proved impossible to determine the yield of the nitrite-mediated reduction of $\mathrm{MbFe}^{\mathrm{IV}}=\mathrm{O}$. Indeed, the reaction of one equivalent of nitrite with $\mathrm{MbFe}^{\mathrm{IV}}=\mathrm{O}$ is slower than the autoreduction of $\mathrm{MbFe}^{\mathrm{IV}}=\mathrm{O}$ to metMb.
Table 4 Amount of nitrite formed from the reaction of $\mathrm{MbFe}^{\mathrm{IV}}=\mathrm{O}$ with one equivalent of $\mathrm{NO}$. Comparison between the amount of nitrate found after the reaction and that present in the NO solution

\begin{tabular}{|c|c|c|c|c|}
\hline $\begin{array}{l}1 \\
\mathrm{pH}\end{array}$ & $\begin{array}{l}2 \\
{\left[\mathrm{MbFe}^{\mathrm{IV}}=\mathrm{O}\right]} \\
(\mu \mathrm{M})\end{array}$ & $\begin{array}{l}3 \\
{\left[\mathrm{NO}_{2}^{-}\right]^{\mathrm{a}}} \\
(\mu \mathrm{M})\end{array}$ & $\begin{array}{l}4 \\
\text { Measured }\left[\mathrm{NO}_{3}^{-}\right] \\
\text {in NO soln. } .^{\mathrm{b}}(\mu \mathrm{M})\end{array}$ & $\begin{array}{l}5 \\
{\left[\mathrm{NO}_{3}{ }^{-}\right] \text {in } \mathrm{NO}} \\
\text { soln. } .^{\mathrm{c}}(\mu \mathrm{M})\end{array}$ \\
\hline 7.0 & 47.3 & 46.6 & 4.3 & 4.3 \\
\hline 7.0 & 47.3 & 47.6 & 4.3 & 3.0 \\
\hline 9.5 & 37.2 & 38.3 & 4.1 & 0.2 \\
\hline 9.5 & 37.2 & 39.6 & 4.1 & 0.4 \\
\hline
\end{tabular}

${ }^{a}$ Concentration of nitrite ions generated from the reaction of $\mathrm{MbFe}^{\mathrm{IV}}=\mathrm{O}$ with $\mathrm{NO}$, calculated from the concentration of nitrite ions found in the reaction solution minus the concentration of nitrite already present in the added $\mathrm{NO}^{\circ}$ solution

${ }^{b}$ Nitrate contamination of the NO solutions determined separately as described in Materials and methods

${ }^{\mathrm{c}}$ Concentration of nitrate ions generated from the reaction of $\mathrm{MbFe}^{\mathrm{IV}}=\mathrm{O}$ with $\mathrm{NO}$, calculated from the concentration of nitrate ions found in the reaction solution minus the concentration of nitrate already present in the added NO solution (column 4)

Analysis of the nitrogen-containing products

The determination of the amount of nitrite and nitrate ions formed from the reaction of $\mathrm{MbFe}^{\mathrm{IV}}=\mathrm{O}$ with one equivalent of $\mathrm{NO}$ at $\mathrm{pH} 7.0$ and 9.5 was carried out by anion chromatography with conductivity detection. As shown in Table 4 (columns 2 and 3), nitrite was always formed quantitatively from the $\mathrm{NO}^{-}$-mediated reduction of $\mathrm{MbFe}^{\mathrm{IV}}=\mathrm{O}$. The concentration of nitrate remained approximately unchanged during the course of the reaction (columns 4 and 5 in Table 4).

As the nitrite-mediated reduction of $\mathrm{MbFe}^{\mathrm{IV}}=\mathrm{O}$ is very slow, the identification of the nature of the nitrogen-containing products had to be carried out by mixing an excess of nitrite with $\mathrm{MbFe}^{\mathrm{IV}}=\mathrm{O}$. At $\mathrm{pH} 7.0$, we found that one equivalent of nitrite, relative to the amount of $\mathrm{MbFe}^{\mathrm{IV}}=\mathrm{O}$, was transformed to half an equivalent of nitrite plus half an equivalent of nitrate (columns 6 and 7 in Table 5). 
Table 5 Amount of nitrite and nitrate formed from the reaction of $\mathrm{MbFe}^{\mathrm{IV}}=\mathrm{O}$ with an excess of nitrite

\begin{tabular}{lllllll}
\hline 1 & 2 & 3 & 4 & 5 & 6 & 7 \\
$\mathrm{pH}$ & $\begin{array}{l}{\left[\mathrm{MbFe}{ }^{\mathrm{IV}}=\mathrm{O}\right]} \\
(\mu \mathrm{M})\end{array}$ & $\begin{array}{l}\text { Added }\left[\mathrm{NO}_{2}^{-}\right] \\
(\mu \mathrm{M})\end{array}$ & $\begin{array}{l}\mathrm{Ex} .\left[\mathrm{NO}_{2}^{-}\right]^{\mathrm{a}} \\
(\mu \mathrm{M})\end{array}$ & $\begin{array}{l}\text { Found }\left[\mathrm{NO}_{2}^{-}\right]^{\mathrm{b}} \\
(\mu \mathrm{M})\end{array}$ & $\begin{array}{l}6 \\
{\left[\mathrm{NO}_{2}^{-}\right]^{\mathrm{c}}} \\
(\mu \mathrm{M})\end{array}$ & $\begin{array}{l}\left.7 \mathrm{NO}_{3}^{-}\right]^{\mathrm{d}} \\
(\mu \mathrm{M})\end{array}$ \\
\hline 7.0 & 25.7 & $216.3(25.7+190.6)$ & 190.6 & $203.9(13.3+190.6)$ & 13.3 & 14.1 \\
7.0 & 43.2 & $248.9(43.2+205.7)$ & 205.7 & $226.4(20.7+205.7)$ & 20.7 & 22.2 \\
\hline
\end{tabular}

${ }^{a}$ Concentration of nitrite added in excess, by considering that only one equivalent reacts with $\mathrm{MbFe}^{\mathrm{IV}}=\mathrm{O}$

${ }^{b}$ Total concentration of nitrite ions found in the protein solution after reaction

${ }^{\mathrm{c}}$ Concentration of nitrite ions generated from the reaction of $\mathrm{MbFe}^{\mathrm{IV}}=\mathrm{O}$ with one equivalent of nitrite, calculated from the total concentration of nitrite ions found in the protein solution after reaction (column 5) minus the concentration of the excess nitrite ions added (column 4)

${ }^{\mathrm{d}}$ Concentration of nitrate ions in the protein solution after reaction with nitrite
Nitration of tyrosine by the $\mathrm{MbFe}^{\mathrm{IV}}=\mathrm{O} /$ nitrite reaction system

Nitrogen dioxide may be generated from the reaction of $\mathrm{MbFe}^{\mathrm{IV}}=\mathrm{O}$ with nitrite. As it is known that $\mathrm{NO}_{2}$ is a potent nitrating agent $[17,24]$, it was of interest to find out whether 3-nitrotyrosine $\left(\mathrm{NO}_{2}\right.$-Tyr) is generated in the course of the nitrite-mediated reduction of $\mathrm{MbFe}^{\mathrm{IV}}=\mathrm{O}$. We thus analyzed the amino acids obtained after complete acid hydrolysis of the reacted protein by HPLC, but no nitrotyrosine was detected. In contrast, when free tyrosine was added to nitrite prior to its reaction with $\mathrm{MbFe}^{\mathrm{IV}}=\mathrm{O}$, less than $1 \%$ nitrotyrosine, relative to the protein, was generated. As shown in Table 6 (entries 1-3), the yield of nitrotyrosine slightly increased with increasing nitrite concentrations.

Finally, we were interested to find out whether $\mathrm{NO}_{2}$-Tyr was generated when $\mathrm{MbFe}^{\mathrm{IV}}=\mathrm{O}$ was mixed with nitrite in the presence of Tyr. As summarized in Table 6 (entries 4-7), when $\mathrm{H}_{2} \mathrm{O}_{2}$ was added to a mixture of nitrite, Tyr, and metMb, significantly larger amounts of $\mathrm{NO}_{2}$-Tyr were formed. The yield of $\mathrm{NO}_{2}$-Tyr increased with increasing nitrite concentrations.

Table 6 Entries 1-3: yield of $\mathrm{NO}_{2}$-Tyr (\% relative to metMb) from the reaction of $\mathrm{MbFe}^{\mathrm{IV}}=\mathrm{O}$ [generated by allowing to react a solution of metMb $(250 \mu \mathrm{M})$ with 1 equiv of $\mathrm{H}_{2} \mathrm{O}_{2}(250 \mu \mathrm{M})$ for $6 \mathrm{~min}$ ] with a solution containing 4 equiv of $\mathrm{Tyr}(1 \mathrm{mM})$ and variable amounts of nitrite. Entries 4-7: yield of $\mathrm{NO}_{2}$-Tyr $(\%$ relative to metMb) from the reaction of a solution of metMb $(250 \mu \mathrm{M}), 4$ equiv of Tyr $(1 \mathrm{mM})$, and variable amounts of nitrite with a solution containing 1 equiv of $\mathrm{H}_{2} \mathrm{O}_{2}(250 \mu \mathrm{M})$

\begin{tabular}{lll}
\hline Entry & $\begin{array}{l}{\left[\mathrm{NO}_{2}^{-}\right]} \\
(\mathrm{mM})\end{array}$ & $\begin{array}{l}\text { Yield } \mathrm{NO}_{2}-\mathrm{Tyr} \\
(\% \text { relative to metMb) }\end{array}$ \\
\hline 1 & 1.0 & $0.28 \pm 0.02$ \\
2 & 2.5 & $0.31 \pm 0.01$ \\
3 & 7.5 & $0.36 \pm 0.01$ \\
4 & 1.0 & $3.1 \pm 0.1$ \\
5 & 2.5 & $5.1 \pm 0.2$ \\
6 & 5.0 & $7.8 \pm 0.1$ \\
7 & 7.5 & $12.9 \pm 0.4$ \\
\hline
\end{tabular}

\section{Discussion}

Nitrogen monoxide (NO) is currently a species of extreme biological interest because of the variety of physiological and pathophysiological functions which have been found to be associated with this inorganic messenger molecule [49, 50, 51]. The cytotoxic effects of NO originate mainly from its reaction with superoxide to generate the powerful oxidizing and nitrating agent peroxynitrite. In contrast, $\mathrm{NO}$ has also been reported to display antioxidant effects $[3,15,17,18$, 19], either by scavenging free radicals to generate less reactive nonradical species $[17,52]$ or by inactivating catalytically active high-valent hemoprotein intermediates $[15,18]$.

In a recent paper, Gorbunov et al. [16] reported that the oxoiron(IV) myoglobin species $\mathrm{MbFe}^{\mathrm{IV}}=\mathrm{O}$ and $\mathrm{MbFe}^{\mathrm{IV}}=\mathrm{O}$ react with $\mathrm{NO}$ to generate metMb. In addition, they showed by ESR and electrospray MS analysis that, in the course of the reaction, no covalent adducts were generated between $\mathrm{NO}^{\circ}$ and the globin or the heme [53]. The reaction of $\mathrm{NO}^{-}$with high-valence myoglobin species has thus been proposed to represent a potential antioxidant role for NO. However, the determination of the rate constant is essential in order to evaluate the biological relevance of this reaction. In the present work, we carried out detailed kinetic and mechanistic analyses of the $\mathrm{NO}^{-}$-mediated reduction of $\mathrm{MbFe}^{\mathrm{IV}}=\mathrm{O}$.

The reaction between $\mathrm{MbFe}^{\mathrm{IV}}=\mathrm{O}$ and $\mathrm{NO}$ is shown to proceed via the rapid formation of an intermediate, which then decays to metMb and nitrite. At $\mathrm{pH} 7.5$ and $20^{\circ} \mathrm{C}$ the second-order rate constant for the formation of this intermediate is $(17.9 \pm 0.5) \times 10^{6} \mathrm{M}^{-1} \mathrm{~s}^{-1}$ and that for its decay is $3.36 \pm 0.05 \mathrm{~s}^{-1}$. The spectrum of the intermediate species displays very characteristic absorption maxima at 631 and $504 \mathrm{~nm}$. A comparison with the spectra of other metMb derivatives with anionic ligands such as the nitro- and nitrato-metMb complexes supports the assignment of this species as a high-spin iron(III) complex (Table 2). The position and the intensity of the Soret band are also comparable with the listed derivatives. Because of the radicallike character of the oxo ligand in $\mathrm{MbFe}^{\mathrm{IV}}=\mathrm{O}[54,55$, 
$56,57]$, it is reasonable to assume that the first step of the reaction is a fast radical recombination (Scheme 1). The observed intermediate may thus be assigned as the nitrito complex $\mathrm{MbFe}^{\mathrm{III}} \mathrm{ONO}$. However, the UV-visible spectra of the nitro- $\left(\mathrm{MbFe}^{\mathrm{III}} \mathrm{NO}_{2}\right)$ and the nitrito- ( $\left.\mathrm{MbFe}^{\mathrm{III}} \mathrm{ONO}\right)$ metMb complexes are almost identical. This observation may suggest that in a second, very rapid step, $\mathrm{MbFe}{ }^{\mathrm{III}} \mathrm{ONO}$ rearranges to $\mathrm{MbFe}^{\mathrm{III}} \mathrm{NO}_{2}$. In this case, the observed intermediate would be $\mathrm{MbFe}^{\mathrm{III}} \mathrm{NO}_{2}$, from which nitrite dissociates in the last step of the reaction.

Nevertheless, several observations can be used to argue against this second possibility. We have recently shown that the spectra of $\mathrm{MbFe}^{\mathrm{III}} \mathrm{NO}_{2}, \mathrm{MbFe}^{\mathrm{III}} \mathrm{ONO}_{2}$, and $\mathrm{MbFe}^{\mathrm{III}} \mathrm{OONO}$ are also very similar [58]. These three complexes can clearly be distinguished from each other because the rates of dissociation of nitrite and nitrate, respectively, are significantly different [58]. Thus, these results imply that when an anionic ligand is coordinated to metMb, the spectrum is not strongly influenced by the type of atom directly bound to the high-spin iron(III). Unfortunately, as shown in Tables 1 and 3, the rates of dissociation of nitrite from $\mathrm{MbFe}{ }^{\mathrm{III}} \mathrm{ONO}\left(k_{2}\right)$ and from $\mathrm{MbFe}^{\mathrm{III}} \mathrm{NO}_{2}\left(k_{-4}\right)$ are very similar and cannot be used to distinguish between the two complexes. This result was unexpected, as it is known that nitrite preferentially binds via the nitrogen atom to iron. Indeed, no nitrito-iron complexes are known, whereas several nitro-iron(III) complexes, and in particular nitro-iron(III) porphyrin complexes, have been synthesized and structurally characterized [59, $60,61,62,63,64]$. However, the similarity between the two dissociation rates $k_{2}$ and $k_{-4}$ might also be a coincidence. The dissociation rate from $\mathrm{MbFe}^{\mathrm{III}} \mathrm{ONO}$ $\left(k_{2}\right)$ has been determined directly with very good accuracy. In contrast, the values for the dissociation rate from $\mathrm{MbFe}^{\mathrm{III}} \mathrm{NO}_{2}\left(k_{-4}\right)$ have been determined indirectly, either from the intercept of the linear plot of the observed pseudo-first-order rate constant versus nitrite concentration (Table 3 ) or from the product of the equilibrium constant $\left(K_{4}\right)$ and the association constants [30]. These values may thus be associated with large errors.

The observation that the values of the dissociation constants increase with decreasing $\mathrm{pH}$ implies that a protonated form of the enzyme facilitates nitrite dissociation. The protonated form of nitrite, $\mathrm{HNO}_{2}$, cannot play a role in this reaction. Indeed, the $\mathrm{p} K_{\mathrm{a}}$ value for nitrous acid is 3.3 and $\mathrm{HNO}_{2}$ is thus present only in trace amounts in the $\mathrm{pH}$ range studied. With the assumption that the $\mathrm{pH}$ dependence originates from a single ionizable residue of the protein, the following relationship between $k_{2}$ and the proton concentration can be derived:

$k_{2}=\left(k_{2}^{\prime} \times\left[\mathrm{H}^{+}\right]\right) /\left(K_{\mathrm{a}}+\left[\mathrm{H}^{+}\right]\right)$

where $k_{2}^{\prime}$ represents the $\mathrm{pH}$-independent first-order dissociation constant and $K_{\mathrm{a}}$ the dissociation constant of the protonable residue. Despite the fact that the reaction was studied at only few $\mathrm{pH}$ values and thus large errors are associated with the results, the experimental data could be fitted to Eq. 1 . The best fit gave a value of $\mathrm{p} K_{\mathrm{a}}=6.5 \pm 0.5$ and $k_{2}^{\prime}=21 \pm 5 \mathrm{~s}^{-1}$. These results suggest the involvement of a histidine residue, very likely the distal histidine, which has been shown to be protonated at $\mathrm{pH}$ values lower than 6 [65]. In the protonated form this histidine swings out of the heme pocket toward the solvent, with consequent opening of the active site [65] and possible acceleration of the dissociation rate. Interestingly, the rate constants measured for the rate of decay of $\mathrm{MbFe}^{\mathrm{III}} \mathrm{OONO}$ to metMb and nitrate are significantly larger but show the same $\mathrm{pH}$ dependence as those obtained for the decay of $\mathrm{MbFe}^{\mathrm{III}} \mathrm{ONO}$ to metMb and nitrite [58].

The rate constant for the reaction of $\mathrm{NO}^{\prime}$ with $\mathrm{MbFe}^{\mathrm{IV}}=\mathrm{O}$ is one order of magnitude larger than that with the corresponding HRP-Compound II $\left(7.4-13 \times 10^{5} \mathrm{M}^{-1} \mathrm{~s}^{-1}\right.$ at $\mathrm{pH} 7.4$ and $20^{\circ} \mathrm{C}$ [66]) and three orders of magnitude larger than that with MPO$\mathrm{Fe}^{\mathrm{IV}}=\mathrm{O}\left(8 \times 10^{3} \mathrm{M}^{-1} \mathrm{~s}^{-1}\right.$ at $\mathrm{pH} 7.0$ and $25^{\circ} \mathrm{C}$ [67]). This difference might arise from the negatively charged character of the proximal histidine. The partly deprotonated histidine is likely to stabilize the higher valence form $\left(\mathrm{MbFe}^{\mathrm{IV}}=\mathrm{O}\right)$ relative to the radical form $\left(\mathrm{MbFe}^{\mathrm{III}}-\mathrm{O}\right)$ and thus slow down the radical recombination (Scheme 1). No intermediate has been reported to be generated in the reaction of NO with HRP- as well as with MPO-Compound II. This result suggests that dissociation of nitrite from $\mathrm{Fe}^{\mathrm{III}}$ is much faster for HRP and MPO than for Mb. This difference is not unexpected as it is conceivable that nitrite dissociates faster from the negatively charged MPO- or HRP$\left[\left(\mathrm{His}^{-}\right) \mathrm{Fe}^{\mathrm{III}} \mathrm{NO}_{2}\right]$ than from the neutral $\mathrm{Mb}-\left[(\mathrm{His}) \mathrm{Fe}^{\mathrm{III}}\right.$ $\mathrm{NO}_{2}$.

Nitrite is one of the major end products of $\mathrm{NO}$ metabolism. It has been shown to be oxidized by peroxidases such as HRP, MPO, and LPO in the presence of hydrogen peroxide, most likely to generate nitrogen dioxide, which can nitrate tyrosine residues free or incorporated into proteins $[22,25]$. The rate constants for the reaction of nitrite with MPO-, LPO-, and HRP-Compound II have recently been reported to vary significantly between the three proteins and to be $(5.5 \pm 0.1) \times 10^{2} \mathrm{M}^{-1} \mathrm{~s}^{-1}$ (at $\mathrm{pH} 7.0$ and $15^{\circ} \mathrm{C}$ [68]), $(3.5 \pm 0.1) \times 10^{4} \mathrm{M}^{-1} \mathrm{~s}^{-1}$ and $13.3 \pm 0.1 \mathrm{M}^{-1} \mathrm{~s}^{-1}$, respectively (at $\mathrm{pH} 7.0$ and room temperature [69]). In the present work we have measured by stopped-flow spectroscopy the rate constant of the reaction between $\mathrm{MbFe}^{\mathrm{IV}}=\mathrm{O}$ and nitrite. The second-order rate constant at $\mathrm{pH} 7.5$ and $20^{\circ} \mathrm{C}$ is $16 \pm 1 \mathrm{M}^{-1} \mathrm{~s}^{-1}$, which is of the same order of magnitude as that for the reaction between nitrite and HRP-Compound II [69], but 1-3 orders of magnitude slower than the corresponding reactions with MPO- and LPO-Compounds II [68, 69]. The $\mathrm{pH}$ dependence in the range 6.1-8.5 shows that, as was reported for the reaction of nitrite with MPO-Compound II [68], the rate of reaction between $\mathrm{MbFe}^{\mathrm{IV}}=\mathrm{O}$ and nitrite decreases with increasing $\mathrm{pH}$ (Table 3). 
The same trend has been found for the rate of reaction of $\mathrm{MbFe}^{\mathrm{IV}}=\mathrm{O}$ with NADH [70] and that of autoreduction of $\mathrm{MbFe}^{\mathrm{IV}}=\mathrm{O}$ [46]. Also for the reaction of $\mathrm{MbFe}^{\mathrm{IV}}=\mathrm{O}$ with nitrite it can be assumed that the $\mathrm{pH}$ dependence originates from a single ionizable residue and thus the experimental data can be fitted to Eq. 1. The best fit gave a value of $\mathrm{p} K_{\mathrm{a}}=6.0 \pm 0.5$ and $k_{3}^{\prime}=(52 \pm 9) \times 10 \mathrm{M}^{-1} \mathrm{~s}^{-1}$. Again, the large errors of these numbers are due to the small number of $\mathrm{pH}$ values studied. The value obtained for the $\mathrm{p} K_{\mathrm{a}}$ of the protonable residue reveals that when the distal histidine is protonated and, thus, turned out toward the solvent, nitrite can diffuse more rapidly into the active site. Alternatively, it has been shown that $\mathrm{MbFe}^{\mathrm{IV}}=\mathrm{O}$, in order to be able to oxidize substrates efficiently, requires the conversion to an activated form in a $\mathrm{pH}$ dependent process [31]. The $\mathrm{p} K_{\mathrm{a}}$ of $\mathrm{MbFe}^{\mathrm{IV}}=\mathrm{O}$ has been estimated to be in the region of 6 [71]. Thus, protonation of the ferryl might also be an explanation for the observed increase in the rate of reaction at lower $\mathrm{pH}$ values.

Analysis of the nitrogen-containing products of the reaction between $\mathrm{MbFe}^{\mathrm{IV}}=\mathrm{O}$ and nitrite reveals that, as has previously been suggested for the corresponding reactions with peroxidases Compound II [17, 22, 24], nitrogen dioxide may be generated in the first step (Scheme 2). In the absence of added substrates, nitrogen dioxide rapidly dimerizes to $\mathrm{N}_{2} \mathrm{O}_{4}$, which then hydrolyzes to nitrite and nitrate. Alternatively, nitrate could be generated from the fast reaction between $\mathrm{MbFe}^{\mathrm{IV}}=\mathrm{O}$ and $\mathrm{NO}_{2} \cdot$ [58].

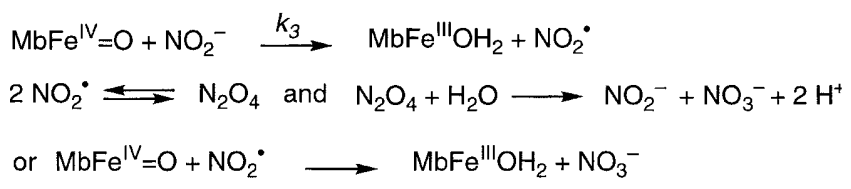

Scheme 2

In the presence of added tyrosine, $\mathrm{NO}_{2}$ leads to the production of very small amounts of 3-nitrotyrosine $\left(\mathrm{NO}_{2}\right.$-Tyr) (Table 6, entries $\left.1-3\right)$, which are likely to be formed from the fast recombination of $\mathrm{NO}_{2}$. with a tyrosyl radical (Tyr) [23]. Two sources are available to generate a tyrosyl radical from tyrosine. $\mathrm{NO}_{2}$ can react with Tyr to yield Tyr at a rate of about $10^{5} \mathrm{M}^{-1} \mathrm{~s}^{-1}[23]$ or, alternatively, $\mathrm{MbFe}^{\mathrm{IV}}=\mathrm{O}$ can oxidize Tyr. As the latter reaction proceeds at a rate of about $40 \mathrm{M}^{-1} \mathrm{~s}^{-1}$ (data not shown), this pathway is probably less relevant. The reaction is thus likely to proceed as shown in Scheme 3. The very low yield of

$$
\begin{aligned}
& 2 \mathrm{MbFe}^{\mathrm{IV}}=\mathrm{O}+2 \mathrm{NO}_{2}^{-} \longrightarrow 2 \mathrm{MbFe}^{\mathrm{III}} \mathrm{OH}_{2}+2 \mathrm{NO}_{2}{ }^{-} \\
& \mathrm{NO}_{2}^{-}+\mathrm{Tyr} \longrightarrow \mathrm{NO}_{2}^{-}+\mathrm{Tyr}^{-} \\
& \mathrm{NO}_{2}^{-}+\mathrm{Tyr}^{\cdot} \longrightarrow \mathrm{NO}_{2} \text {-Tyr }^{-\mathrm{Ty}}
\end{aligned}
$$

Scheme 3

$$
\begin{aligned}
& \mathrm{MbFe}^{\mathrm{III}} \mathrm{OH}_{2}+\mathrm{H}_{2} \mathrm{O}_{2} \longrightarrow \mathrm{MbFe}^{\mathrm{IV}}=\mathrm{O}+\mathrm{H}_{2} \mathrm{O} \\
& \mathrm{MbFe}^{\mathrm{IV}}=\mathrm{O}+\mathrm{Tyr} \longrightarrow \mathrm{MbFe}{ }^{\mathrm{IV}}=\mathrm{O}+\mathrm{Tyr}^{\circ} \\
& \mathrm{MbFe}^{\mathrm{IV}}=\mathrm{O}+\mathrm{NO}_{2}-\mathrm{MbFe}^{\mathrm{IV}}=\mathrm{O}+\mathrm{NO}_{2}{ }^{\circ} \\
& \mathrm{MbFe}^{\mathrm{IV}}=\mathrm{O}+\mathrm{NO}_{2}^{-} \longrightarrow \mathrm{MbFe}^{\mathrm{III}} \mathrm{OH}_{2}+\mathrm{NO}_{2}{ }^{-} \\
& \mathrm{NO}_{2}{ }^{-}+\mathrm{Tyr} \longrightarrow \mathrm{NO}_{2}-\mathrm{Tyr}
\end{aligned}
$$

\section{Scheme 4}

$\mathrm{NO}_{2}$-Tyr is probably due to the concurrent fast reaction of $\mathrm{NO}_{2}$ with $\mathrm{MbFe}^{\mathrm{IV}}=\mathrm{O}$ (Scheme 2) [58].

Significantly larger amounts of $\mathrm{NO}_{2}$-Tyr were obtained when nitrite was reacted in situ with $\mathrm{MbFe}^{\mathrm{IV}}=\mathrm{O}$ in the presence of added free tyrosine (Table 6, entries 4-7). These results indicate that, in order to generate higher yields of $\mathrm{NO}_{2}$-Tyr, a further source of tyrosyl radicals must be present in the system. Indeed, Tyr may be first generated from the reaction of $\mathrm{Tyr}$ with $\mathrm{MbFe}^{\mathrm{IV}}=\mathrm{O}$ and then rapidly recombine with $\mathrm{NO}_{2}$ (Scheme 4). At higher nitrite concentrations, larger amounts of $\mathrm{NO}_{2}$ are formed, possibly also from the reaction of nitrite with $\mathrm{MbFe}^{\mathrm{IV}}=\mathrm{O}$, and trap Tyr more efficiently, resulting in larger yields of $\mathrm{NO}_{2}$-Tyr. This in situ reaction should represent a better model for the physiological conditions, as it is more likely that all the reagents are present contemporaneously. Thus, our data imply that the reaction of $\mathrm{H}_{2} \mathrm{O}_{2}$ with metMb in the presence of nitrite may represent an alternative route, in addition to peroxynitrite-mediated nitration $[26,27,28]$, to generate nitrotyrosine in vivo.

\section{Conclusions}

In the present work we have determined the rate constant for the reaction between $\mathrm{MbFe}^{\mathrm{IV}}=\mathrm{O}$ and $\mathrm{NO}$ to be $(17.9 \pm 0.5) \times 10^{6} \mathrm{M}^{-1} \mathrm{~s}^{-1}$ at $\mathrm{pH} 7.5$ and $20^{\circ} \mathrm{C}$. This reaction proceeds at a rate comparable to that for the reaction between $\mathrm{MbFeO}_{2}$ and $\mathrm{NO}\left\{(43.6 \pm 0.5) \times 10^{6}\right.$ $\mathrm{M}^{-1} \mathrm{~s}^{-1}$ at $\mathrm{pH} 7.5$ and $20^{\circ} \mathrm{C}$ [58]\}. Thus, it may represent a valid alternative reaction between myoglobin and $\mathrm{NO}$. The high-valence form of $\mathrm{Mb}$ has been proposed to be at least in part responsible for oxidative lesions found on ischemic/reperfused tissues [6]. Other one-electron reductants present in vivo such as ascorbate react with $\mathrm{MbFe}^{\mathrm{IV}}=\mathrm{O}$ at a significantly lower rate $\left(2.7 \pm 0.810^{6} \mathrm{M}^{-1} \mathrm{~s}^{-1}\right.$ at $\mathrm{pH} 7.0$ and $\left.25^{\circ} \mathrm{C}\right)$ [13]. Therefore, as the products generated from the reaction of $\mathrm{MbFe}^{\mathrm{IV}}=\mathrm{O}$ with $\mathrm{NO}$ are not strong oxidizing species, this reaction might represent a pathway for detoxification of $\mathrm{MbFe}^{\mathrm{IV}}=\mathrm{O}$ in vivo.

In contrast, the reaction between nitrite and $\mathrm{MbFe}^{\mathrm{IV}}=\mathrm{O}$ proceeds at a significantly lower rate $(16 \pm$ $1 \mathrm{M}^{-1} \mathrm{~s}^{-1}$ at $\mathrm{pH} 7.5$ and $20^{\circ} \mathrm{C}$ ) and generates the nitrating agent nitrogen dioxide. Our results suggest that this reaction may play a role only in the absence 
of peroxynitrite, which also reacts significantly faster with $\mathrm{MbFe}^{\mathrm{IV}}=\mathrm{O}\left\{(2.2 \pm 0.1) \times 10^{4} \mathrm{M}^{-1} \mathrm{~s}^{-1}\right.$ at $\mathrm{pH} 7.3$ and $\left.20^{\circ} \mathrm{C}[72]\right\}$, or when $\mathrm{NO}^{\prime}$ has been completely converted to nitrite. However, we have also shown that, in the presence of nitrite and added free tyrosine, the reaction of metMb with $\mathrm{H}_{2} \mathrm{O}_{2}$ can yield significant amounts of $\mathrm{NO}_{2}$-Tyr. Under pathophysiological conditions in which the nitrite level can be elevated, this reaction may thus contribute to nitration of tyrosine residues either free or incorporated into proteins. The results reported are important for a better understanding of the interaction of $\mathrm{NO}^{-}$with hemoproteins with oxidase activity under inflammatory or ischemic conditions, when generation of $\mathrm{NO}$, nitrite, and $\mathrm{H}_{2} \mathrm{O}_{2}$ is elevated.

Acknowledgements We thank Michael Exner for his help with the HPLC measurements. These studies were supported by the ETH Zürich.

\section{References}

1. Gunther MR, Sampath V, Caughey WS (1999) Free Radical Biol Med 26:1388-1395

2. Turner JJO, Rice-Evans CA, Davies MJ, Newman ES (1990) Biochem Soc Trans 18:1056-1059

3. Grisham MB, Granger DN, Lefer DJ (1998) Free Radical Biol Med 25:404-433

4. Grisham MB, Everse J (1991) In: Everse J, Everse KE, Grisham MB (eds) Peroxidases in chemistry and biology. CRC Press, Boston, pp 335-344

5. Chance B, Sies H, Boveris A (1979) Physiol Rev 59:527-605

6. Galaris D, Eddy L, Arduini A, Cadenas E, Hochstein P (1989) Biochem Biophys Res Commun 160:1162-1168

7. Giulivi C, Cadenas E (1994) Methods Enzymol 233:189-202

8. Harel S, Kanner J (1988) Free Radical Res Commun 5:21-33

9. Berzofsky JA, Peisach J, Blumberg WE (1971) J Biol Chem 246:3367-3377

10. Arduini A, Eddy L, Hochstein P (1990) Free Radical Biol Med 9:511-513

11. Galaris D, Sevanian A, Cadenas E, Hochstein P (1990) Arch Biochem Biophys 281:163-169

12. Newman ESR, Rice-Evans CA, Davies MJ (1991) Biochem Biophys Res Commun 179:1414-1419

13. Kröger-Ohlsen M, Skibsted LH (1997) J Agric Food Chem 45:668-676

14. Dee G, Rice-Evans C, Obeyesekera S, Meraji S, Jacobs M, Bruckdorfer KR (1991) FEBS Lett 294:38-42

15. Wink DA, Hanbauer I, Laval F, Cook JA, Krishna MC, Mitchell JB (1994) In: Chiueh CC, Gilbert DL, Colton CA (eds) Annual review of the New York Academy of Science. New York Academy of Science, New York, pp 265-278

16. Gorbunov NV, Osipov AN, Day BW, Zayas-Rivera B, Kagan VE, Elsayed NM (1995) Biochemistry 34:6689-6699

17. Wink DA, Cook JA, Krishna MC, Hanbauer I, DeGraff W, Gamson J, Mitchell JB (1995) Arch Biochem Biophys 319:402-407

18. Jourd'heuil D, Mills L, Miles AM, Grisham MB (1998) Nitric Oxide Biol Chem 2:37-44

19. Gorbunov NV, Tyurina YY, Salama G, Day BW, Claycamp HG, Argyros G, Elsayed NM, Kagan VE (1998) Biochem Biophys Res Commun 244:647-751

20. Kaur H, Halliwell B (1994) FEBS Lett 350:9-12

21. Torre D, Ferrario G, Speranza F, Orani A, Fiori GP, Zeroli C (1996) J Clin Pathol 49:574-576
22. Klebanoff SJ (1993) Free Radical Biol Med 14:351-360

23. Prütz WA, Mönig H, Butler J, Land EJ (1985) Arch Biochem Biophys 243:125-134

24. Goss SPA, Singh RJ, Hogg N, Kalyanaraman B (1999) Free Radical Res 31:597-606

25. van der Vliet A, Eiserich JP, Halliwell B, Cross CE (1997) J Biol Chem 272:7617-7625

26. Reiter CD, Teng R-J, Beckman JS (2000) J Biol Chem 275:32460-32466

27. Souza JM, Daikhin E, Yudkoff M, Raman CS, Ischiropoulos H (1999) Arch Biochem Biophys 371:169-178

28. Ischiropoulos H (1998) Arch Biochem Biophys 356:1-11

29. Østdal H, Daneshvar B, Skibsted LH (1996) Free Radical Res 24:429-438

30. Antonini E, Brunori M (1971) Hemoglobin and myoglobin in their reactions with ligands. North-Holland, Amsterdam

31. Fenwick CW, English AM, Wishart JF (1997) J Am Chem Soc 119:4758-4764

32. Herold S (1999) Arch Biochem Biophys 372:393-398

33. Giulivi C, Cadenas E (1998) Free Radical Biol Med 24:269-279

34. Gunther MR, Sturgeon BE, Mason RP (2000) Free Radical Biol Med 28:709-719

35. Schmidt HHHW, Kelm M (1996) In: Feelisch M, Stamler JS (eds) Methods in nitric oxide research. Wiley, New York, pp 491-497

36. George P, Irvine DH (1952) Biochem J 52:511-517

37. Tajima G-I, Shikama K (1993) Int J Biochem 25:101-105

38. Herold S (1999) FEBS Lett 443:81-84

39. Sono M, Dawson JH (1982) J Biol Chem 257:5496-5502

40. King NK, Winfield ME (1963) J Biol Chem 238:1520-1528

41. Osawa Y, Korzekwa K (1991) Proc Natl Acad Sci USA 88:7081-7085

42. Gunther MR, Hsi LC, Curtis JF, Gierse JK, Marnett LJ, Eling TE, Mason RP (1997) J Biol Chem 272:17086-17090

43. Goodwin DC, Gunther MR, Hsi LC, Crews BC, Eling TE, Mason RP, Marnett LJ (1998) J Biol Chem 273:8903-8909

44. Sanakis Y, Goussias C, Mason RP, Petrouleas V (1997) Biochemistry $36: 1411-1417$

45. Szalai VA, Brudvig GW (1996) Biochemistry 35:15080-15087

46. Kröger-Ohlsen MV, Andersen ML, Skibsted LH (1999) Free Radical Res 30:305-314

47. Wazawa T, Matsouka A, Tajima G, Sugawara Y, Nakamura K, Shikama K (1992) Biophys J 63:544-550

48. Alayash AI, Brockner Ryan BA, Eich RF, Olson JS, Cashon RE (1999) J Biol Chem 274:2029-2037

49. Moncada S, Palmer RMJ, Higgs EA (1991) Pharmacol Rev 43:109-142

50. Beckman JS, Koppenol WH (1996) Am J Physiol 271:C1424-C1437

51. Wink DA, Feelisch M, Vadovotz Y, Fukuto J, Grisham MB (1999) In: Gilbert DL, Colton CA (eds) Reactive oxygen species in biological systems: an interdisciplinary approach. Kluwer/Plenum, New York, pp 245-291

52. Rubbo H, Freeman BA (1996) Methods Enzymol 269:385-394

53. Osipov AN, Gorbunov NV, Day BW, Elsayed NM, Kagan VE (1996) Methods Enzymol 268:193-203

54. Filatov M, Harris N, Shaik S (1999) J Chem Soc Perkin Trans 2 399-410

55. Sevin A, Fontecave M (1986) J Am Chem Soc 108:3266-3272

56. Hanson LK, Chang CK, Davis MS, Fajer J (1981) J Am Chem Soc 103:663-670

57. Sawyer DT (1987) Comments Inorg Chem 6:103-121

58. Herold S, Exner M, Nauser T (2001) Biochemistry 40:3385-3395

59. Ellison MK, Schulz CE, Scheidt WR (1999) Inorg Chem 38:100-108

60. Munro OQ, Scheidt WR (1998) Inorg Chem 37:2308-2316 
61. Frangione M, Port J, Baldiwala M, Judd A, Galley J, DeVega M, Linna K, Caron L, Anderson E, Goodwin JA (1997) Inorg Chem 36:1904-1911

62. Nasri H, Haller KJ, Wang Y, Huynh BH, Scheidt WR (1992) Inorg Chem 31:3459-3467

63. Nasri H, Wang Y, Huynh BH, Walker FA, Scheidt WR (1991) Inorg Chem 30:1483-1489

64. Nasri H, Goodwin JA, Scheidt WR (1990) Inorg Chem 29:185-191

65. Miller LM, Patel M, Chance MR (1996) J Am Chem Soc 118:4511-4517

66. Glover RE, Koshkin V, Dunford HB, Mason RP (1999) Nitric Oxide Biol Chem 3:439-444
67. Abu-Soud HM, Hazen SL (2000) J Biol Chem 275:37524-37532

68. Burner U, Furtmüller PG, Kettle AJ, Koppenol WH, Obinger C (2000) J Biol Chem 275:20597-20601

69. Gebicka L (1999) Acta Biochim Polon 46:919-927

70. Mikkelsen A, Skibsted LH (1995) Z Lebensm Unters Forsch 200:171-177

71. Foote N, Gadsby PMA, Greenwood C, Thomson AJ (1989) Biochem J 261:515-522

72. Exner M, Herold S (2000) Chem Res Toxicol 13:287-293 